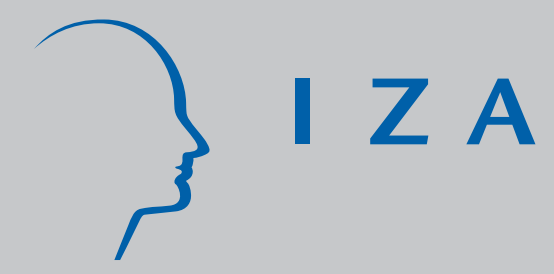

IZA DP No. 4029

Female Labor Supply Differences by Sexual Orientation: A Semi-Parametric Decomposition Approach

Heather Antecol

Michael D. Steinberger

February 2009 


\title{
Female Labor Supply Differences by Sexual Orientation: A Semi-Parametric Decomposition Approach
}

\author{
Heather Antecol \\ Claremont McKenna College \\ and IZA \\ Michael D. Steinberger \\ Pomona College \\ and UCLA Williams Institute
}
Discussion Paper No. 4029
February 2009

\author{
IZA \\ P.O. Box 7240 \\ 53072 Bonn \\ Germany \\ Phone: +49-228-3894-0 \\ Fax: +49-228-3894-180 \\ E-mail: iza@iza.org
}

\begin{abstract}
Any opinions expressed here are those of the author(s) and not those of IZA. Research published in this series may include views on policy, but the institute itself takes no institutional policy positions.

The Institute for the Study of Labor (IZA) in Bonn is a local and virtual international research center and a place of communication between science, politics and business. IZA is an independent nonprofit organization supported by Deutsche Post Foundation. The center is associated with the University of Bonn and offers a stimulating research environment through its international network, workshops and conferences, data service, project support, research visits and doctoral program. IZA engages in (i) original and internationally competitive research in all fields of labor economics, (ii) development of policy concepts, and (iii) dissemination of research results and concepts to the interested public.
\end{abstract}

IZA Discussion Papers often represent preliminary work and are circulated to encourage discussion. Citation of such a paper should account for its provisional character. A revised version may be available directly from the author. 


\title{
ABSTRACT \\ Female Labor Supply Differences by Sexual Orientation: A Semi-Parametric Decomposition Approach ${ }^{*}$
}

\begin{abstract}
Using 2000 U.S. Census data we illustrate the importance of accounting for household specialization in lesbian couples when examining the sexual orientation gap in female labor supply. Specifically, we find the labor supply gap is substantially larger between married women and partnered lesbian women who specialize in market production (primary earners) than between married women and partnered lesbian women who specialize in household production (secondary earners). Using a semi-parametric decomposition approach, we further show that the role of children in explaining the mean labor supply gap by sexual orientation is greatly understated if the household division of labor between household and market production is not taken into account. Finally, we illustrate that controlling for children significantly reduces differences between married women and secondary lesbian earners both in terms of the decision to remain attached to the labor market (the extensive margin), as well as in terms of annual hours of work conditional on working (the intensive margin). Further, the effect of controlling for children is not uniform across the distribution of conditional annual hours; instead it primarily reduces the percentage of secondary lesbian earners working extremely high annual hours.
\end{abstract}

JEL Classification: J22, J24

Keywords: household specialization, female labor supply, sexual orientation

Corresponding author:

Heather Antecol

Robert Day School of Economics and Finance

Claremont McKenna College

500 E. Ninth Street

Claremont, CA 91711-6400

USA

E-mail: hantecol@cmc.edu

\footnotetext{
* All STATA MP 9.0 programs used to analyze the public use 2000 U.S. Census from IPUMS are available from authors upon request.
} 


\section{Introduction}

Partnered lesbian women have substantially higher labor supply than married women (Tebaldi and Elmslie 2006 and Leppel 2008). What might account for the sexual orientation gap in female labor supply? Everyday conversation and casual empiricism suggests that partnered lesbian women have a stronger attachment to the labor market relative to married women due to their choice to have fewer children than their married counterparts; yet this has not been formally analyzed. The primary goal of this study is to determine the role observable characteristics, particularly children, play in explaining the differences in labor supply between partnered lesbian women and married women.

While empirical research on the determinants of partnered lesbian women's labor supply is limited, ${ }^{1}$ the determinants of married women's labor supply have been studied in great detail (see Blundell and MaCurdy 1999 for a survey of the literature). In general, married women's labor supply is found to be positively related to own wages, negatively related to spouse wages and non labor income, and negatively related to the presence of children, particularly young children, in the household. ${ }^{2}$ Importantly, the same control variables are not found to have the same effect on married men's labor supply. In particular, men are not responsive to their wife's earnings and tend to have higher labor supply as a result of the presence of children.

These findings are consistent with a traditional division of labor into market and household work which results in married men being viewed as the primary earners and married

\footnotetext{
${ }^{1}$ The majority of the empirical literature on lesbian women focuses on the sexual orientation wage gap (see for example, Badgett 1995a; Klawitter and Flatt 1998; Clain and Leppel 2001; Berg and Lien 2002; Black et al. 2003; Blandford 2003; Antecol, Jong and Steinberger 2008).

${ }^{2}$ See Mroz (1987) for tests of the exogeneity assumption of (own and spousal) wage rates and children in the household. The results are robust when endogeneity concerns with respect to children and wages (own and spousal) are taken into account.
} 
women being viewed as the secondary earners. ${ }^{3}$ In particular, Becker (1981) argues that increasing returns from investments in specific human capital encourages a division of labor in market work and household work among household members. The sexual division of labor, however, arises from intrinsically different comparative advantages of men and women (e.g., in the production of children) which would determine the direction of the division of tasks by gender. This in turn leads to differences in specific human capital accumulation which reinforces the intrinsically different comparative advantages of men and women.

Even in the face of rising female labor force participation, increased divorce rates, and lower fertility, male and female earnings would not be equalized (Becker 1985). Specifically, Becker argues that married women with household responsibilities (e.g., child care and food preparation) would expend less energy on market work, make lower investments in marketoriented human capital, face lower hourly earnings and choose less demanding jobs/occupations than married men (even when they work the same number of hours) because household responsibilities are time and effort intensive relative to leisure and other non-market uses of time by men. Moreover, married women would have lower labor force participation than their husbands because of the lower earnings they would face (due to less energy expended on market work and lower investments in market-oriented human capital) and a full equilibrium could involve complete specialization by married women in household production.

Although married men have increased their time spent on child care production, there is strong evidence that married women continue to spend more time on child care production than their spouses (Kalenkoski, Ribar, and Stratton 2005; 2007; Bianchi, Robinson, and Milkie 2006; Lundberg, Pabilonia, and Ward-Batts 2007; Drago and Lee 2008a; 2008b). In addition, the

\footnotetext{
${ }^{3}$ The terms "primary earner" and "secondary earner" are used solely to reflect an individual's connection to market work and household work, respectively. Thus, they are not meant to reflect any decision-making authority in the household.
} 
sociology literature argues that married women are more likely to identify themselves in the context of family and market work while married men are more likely to identify themselves in the context of market work alone (see for example, Bielby and Bielby 1989). Finally, there is a large literature that tests the specialization hypothesis (Kenny 1983; Daniel 1992; Loh 1996; Gray 1997; Hersch and Stratton 2000; Stratton 2002; Bardasi and Taylor 2008). In general, these studies show support that the preponderance of married couples share a traditional division of labor in household and market work.

Becker (1985) notes that even if women did not have an intrinsic comparative advantage in household work, a division of labor between household and market work for married couples would still be beneficial if specific human capital investment remained important or if the level of spousal energy differed. The division of labor, however, would no longer be based on gender and the household member who specializes in household production would continue to earn less than their spouse. This has important implications for studying differences in women's labor supply by sexual orientation as partnered lesbians, like their married counterparts, face incentives to divide labor between household production (secondary earners) and market production (primary earners). ${ }^{4}$

We are aware of only two studies that examine the sexual orientation gap in labor supply (Tebaldi and Elmslie 2006 and Leppel 2008). Although these studies make important strides in increasing our understanding of the sexual orientation gap in labor supply, they suffer from two

\footnotetext{
${ }^{4}$ While the potential application of Becker's model of household specialization to same-sex couples has been previously suggested (see for example, Badgett 1995b, 2001), to the best of our knowledge the application of the specialization hypothesis to same-sex couples has not been formally tested in the economics literature. There is a limited literature in psychology and sociology exploring the division of household chores in nonrandom, usually small-scale samples of lesbian and gay male households (see Peplau and Fingerhut 2007 for a survey of the literature). While these studies tend to show that same-sex couples divide household chores more equally than married couples, Carrington (1999) cautions that the findings in these studies may be biased by a desire of same-sex couples to perceive their division of household chores as egalitarian even when, as he finds, the objective reality in same-sex households shows a division of chores that is similar to married couples.
} 
key shortcomings. First, these studies simply document the existence of the sexual orientation gap; they do not explicitly attempt to determine the role of various observed characteristics in explaining differences in labor supply by sexual orientation. Second, these studies combine all partnered lesbians into a single group. Therefore they do not address the division of labor within partnered lesbian households. We argue controlling for household specialization is crucial as it allows one to account for differences in labor supply within lesbian couples by earner status. Further, as we have shown above for married couples, the impact of children, wages, and nonlabor income on labor supply will be different depending on whether the household member is the primary or secondary earner. Hence the relative roles of observed characteristics (particularly children) in explaining the sexual orientation gap in labor supply may be biased if the division of labor in partnered lesbian couples is not taken into account.

We attempt to address these shortcomings in the literature on differences in labor supply by sexual orientation. Specifically, using 2000 U.S. Census data we first document the differences in labor supply (annual hours of work unconditional on participating in the labor market) by earner status in partnered lesbian households ${ }^{5}$ and compare and contrast these to married men (primary earners) and women (secondary earners). The labor supply of primary earners is significantly greater than that of secondary earners irrespective of sexual orientation, although the labor supply differential within lesbian households is smaller than in married households. Further, we illustrate that, in line with the specialization hypothesis, the labor supply decisions of primary and secondary earners in partnered lesbian households are differentially affected by observed characteristics, particularly children, in a manner that is consistent with those found for married women (men).

\footnotetext{
${ }^{5}$ We identify earner status in lesbian households based on differences in yearly earnings of the partners. This identification strategy is discussed in detail in the data section.
} 
We then use a semi-parametric decomposition approach to analyze the mean female sexual orientation gap in labor supply. We find that the role of children in explaining the mean labor supply gap by sexual orientation is greatly understated if the division of labor in partnered lesbian couples between household and market work is not taken into account. In particular, we find that children explain a much larger portion of the mean labor supply gap between married women and secondary lesbian earners (56 percent) than between married women and primary lesbian earners (9 percent). Moreover, all observable characteristics (including children) account for 59 percent of the mean labor supply gap between married women and secondary lesbian earners, but only 15 percent of the gap between married women and primary lesbian earners. Finally, we illustrate that controlling for children significantly reduces differences between married and secondary lesbian earners both in terms of the decision to remain attached to the labor market (the extensive margin), as well as in terms of annual hours of work conditional on working (the intensive margin). The effect of controlling for children however is not uniform across the distribution of conditional annual hours; instead it primarily reduces the percentage of secondary lesbian earners working extremely high annual hours.

The next section discusses the data. Section III discusses the determinants of labor supply by sexual orientation and earner status. Section IV presents the semi-parametric decomposition results. The conclusions are presented in Section V.

\section{Data}

We use data from the Integrated Public Use Microdata Series (IPUMS) 5\% sample of the 2000 United States Census. This data is ideal for our purposes because it has detailed information on sexual orientation group (heterosexual and same-sex), labor market outcomes (e.g., usual hours worked, weeks worked, labor force participation, wages), and demographics 
(e.g., age, education, marital status, region). In addition, the census is a very large nationally representative data set which allows us to identify large enough samples by sexual orientation group.

The sample is restricted to women who are in one of two couple types: married heterosexual or cohabiting same-sex partner. Henceforth, we refer to these couple types as married and lesbian. We create two indicator variables (married and lesbian) based on the respondent's relationship to the head of the household. ${ }^{6}$ The married indicator equals one if the respondent indicates that she is married to a male partner, and zero otherwise. Similarly, the lesbian indicator equals ones if the respondent indicates that she is in an unmarried partnership with a female, and zero otherwise. ${ }^{7}$

The sample is further restricted to include only couples where both partners are nonHispanic white, between the ages of $25-54$, and have positive observation weight. A couple is also excluded if either of the partners is employed in the armed forces. In addition, we exclude households with imputed values for sex, marital status, or relationship to head of household for either partner. We exclude households with imputed values for these variables because of misgivings about the accuracy of the 2000 U.S. Census data's identification of the same-sex cohabiting population due to coding errors. ${ }^{8}$ The elimination of potentially miscoded heterosexual couples from the same-sex couple data ensures estimates that are more reliable. Finally, we exclude couples with imputed values for our variables of interest (usual hours and

\footnotetext{
${ }^{6}$ Relationship to household head includes the following categories: spouse, child, in-laws, unmarried partner, and other non-relatives. We focus solely on the spouse and unmarried partner categories.

${ }^{7}$ As it is unclear whether cohabiting lesbian couples more closely mirror married heterosexual couples or a combination of married heterosexual couples and cohabiting heterosexual couples, we also considered a third couple type, heterosexual which takes a value of one if a heterosexual woman is either married or cohabiting, and zero otherwise. Results are similar and available upon request.

${ }^{8}$ For a detailed discussion of coding errors in the 2000 U.S. Census see Black et al. (2002).
} 
weeks worked). These restrictions result in a final sample size of 965,469 married and 6,502 lesbian women.

Our measure of labor supply is annual hours of work unconditional on participation in the labor market. Unconditional annual hours are measured as the product of usual hours worked per week times weeks worked in the past calendar year (ranges from 0 to 5148). Lesbians have higher labor supply than married women. Specifically, married women (lesbians) on average work 1360 (1949) hours per year (see Table 1, columns 1 and 2), a gap of 589 an hours. In other words, lesbian women work 43 percent more unconditional annual hours per year than married women. ${ }^{9}$ While the sexual orientation gap in usual weekly hours is larger than the sexual orientation gap in weeks worked last year (i.e., lesbian women usually work 38 percent more hours than married women and work 26 percent more weeks than married women), both underlying components of unconditional annual hours are economically important.

How much of the gap in unconditional annual hours is due to the extensive margin (the decision to work a positive number of hours) versus the intensive margin (conditional on participating in the labor market, the decision to adjust annual hours of work)? To answer this we first note that for each group, average unconditional annual hours is equal to average conditional annual hours times the average probability of working a positive number of hours (henceforth referred to as labor force attachment). Thus the gap in unconditional annual hours between lesbian and married women is

$$
\overline{A H}_{L}-\overline{A H}_{M}=\overline{C A H}_{L} * \overline{L A}_{L}-\overline{C A H}_{M} * \overline{L A}_{M}
$$

where $\overline{A H}$ is average unconditional annual hours, $\overline{C A H}$ is average conditional annual hours, $\overline{L A}$ is average labor force attachment and $\mathrm{L}$ and $\mathrm{M}$ denote lesbian and married women,

\footnotetext{
${ }^{9}$ This is calculated as (lesbian annual hours-married women annual hours)/married women annual hours.
} 
respectively. We now add and subtract from equation 1 the counterfactual unconditional annual hours for lesbian women if they had the labor force attachment of married women $\left(\overline{C A H}_{L} * \overline{L A}_{M}\right)$

$$
\overline{A H}_{L}-\overline{A H}_{M}=\overline{C A H}_{L} * \overline{L A}_{L}-\overline{C A H}_{L} * \overline{L A}_{M}+\overline{C A H}_{L} * \overline{L A}_{M}-\overline{C A H}_{M} * \overline{L A}_{M}
$$

Collecting terms:

$$
\overline{A H}_{L}-\overline{A H}_{M}=\left(\overline{L A}_{L}-\overline{L A}_{M}\right) * \overline{C A H}_{L}+\left(\overline{C A H}_{L}-\overline{C A H}_{M}\right) * \overline{L A}_{M}
$$

The first term represents the portion of the gap due to the extensive margin and the second term represents the portion of the gap due to the intensive margin. ${ }^{10}$ Dividing the portion of the gap explained by the extensive (intensive) margin by the total gap in unconditional annual hours gives the percent explained by the extensive (intensive) margin.

According to Table 1, lesbian women work 341 more hours per year (conditional on working) and are 16 percentage points more attached to the labor force than their married counterparts. Using the methodology described above, we find that the extensive and intensive margins explain 54 and 46 percent of the sexual orientation gap in unconditional annual hours, respectively. ${ }^{11}$ Given both the extensive and intensive margins play a role, we use unconditional annual hours (henceforth referred to as annual hours) as our main measure of labor supply as it is a combination of the two margins.

We argue that combining all lesbians into one group is incorrect as it does not take into account the specialization hypothesis, that is, the division of labor between household and

\footnotetext{
${ }^{10}$ Instead, we could have added and subtracted from equation 1 the counterfactual unconditional annual hours for lesbian women if they had the conditional annual hours of married women $\left(\overline{C A H}_{M} * \overline{L A}_{L}\right)$. This adjusts the intensive margin, as opposed to the extensive margin (as is done in equation 2), and yields a slightly larger role for the intensive margin (results available upon request).

${ }^{11}$ Another indicator of the intensive margin is, conditional on working, the decision to work full-time (35 hours or more) vs. part-time (less than 35 hours). We find that lesbian women are 18 percentage points less likely to work part-time than their married counterparts (see Appendix Table 1, columns 1 and 2) which again illustrates the importance of the intensive margin.
} 
market work among lesbian partners. Becker (1985) argues that this division of labor would result in the household member who specializes in household production earning less than their partner. Moreover, he argues this specialization will occur as long as specific human capital investment remains important or if the level of partner energy differs.

We identify earner status within lesbian households based on the respondent's annual earnings from wages/salary and business income. ${ }^{12}$ We define the "primary" earner specializing in market work as the lesbian partner with higher annual earnings and the "secondary" earner specializing in household work as the lesbian partner with lower annual earnings. ${ }^{13}$ This identification strategy reflects Becker's (1985) argument that the division of labor between market and household production within a household results in the household member who specializes in market (household) production earning more (less) than their partner. It is also consistent with the literature on the specialization hypothesis among married couples which suggests that generally men are primary earners and women secondary earners in married households (Kenny 1983; Daniel 1992; Loh 1996; Gray 1997; Hersch and Stratton 2000; Stratton 2002; Bardasi and Taylor 2008) as 81 percent of married women are identified as secondary earners under our strategy.

The differences in labor supply between married women and lesbian women discussed above are misleading as the lesbian sample includes both primary and secondary lesbian earners,

\footnotetext{
${ }^{12} \mathrm{We}$ also consider an alternative identification strategy to determine the division of labor within lesbian households. This second strategy relies on the census householder definition which is based on the question "Start with the person, or one of the people living here who owns, is buying, or rents this house, apartment, or mobile home. If there is not such person, start with any adult living or staying here." Specifically, we define the person who owns or rents the house, the householder, as the "primary" earner and the partner of the householder as the "secondary" earner. We argue that this definition may reflect how the partners within lesbian households selfidentify as the primary and secondary earner in the household and is a useful way to corroborate the results of our main analysis without resorting to yearly earnings to identify household specialization. The findings using the householder definition are similar to our main analysis (although the magnitudes of the effects are smaller). See Appendix Tables 2 and 3.

${ }^{13}$ In four percent of lesbian households there is no person who clearly earns more than her partner either because both partners have the same annual earnings, or both earn above the census topcoded earnings cutoff. For these households we assign the lesbian partner who is the householder (partner) as the primary (secondary) earner.
} 
whereas the married sample includes predominately secondary earners. In particular, Table 1 reveals that married women have the lowest annual hours (1360), followed by secondary lesbian earners (1712), primary lesbian earners (2186) and married men, not surprisingly, have the highest annual hours (2228, not reported). ${ }^{14}$ Reflecting the importance of accounting for household specialization, the sexual orientation labor supply gap is much smaller between married women and secondary lesbian earners (352 annual hours) than between married women and primary lesbian earners (826 annual hours) (see Table 1). ${ }^{15}$ Finally, secondary lesbian earners are more closely aligned to married women (i.e., secondary earners) and primary lesbian earners are more closely aligned to married men (i.e., primary earners) when we focus on the extensive and intensive margins of the labor supply decision. ${ }^{16}$ These patterns illustrate the importance of correctly accounting for the specialization hypothesis within the lesbian sample.

In order to understand the patterns in labor supply by sexual orientation, a number of control variables need to be included in the analysis. It is often posited that lesbian women earn more than their heterosexual counterparts because they are less likely to have children, and are therefore more attached to the labor market (e.g., Klawitter and Flatt 1998; Berg and Lien 2002; Blandford 2003; and Black et al 2003). Moreover, the literature on married women's labor

\footnotetext{
${ }^{14}$ The smaller labor supply differential within lesbian households relative to married households is consistent with research showing that household specialization in married couples is affected by the legal institution of marriage. Specifically, Stevenson (2007) shows that unilateral divorce laws reduced household specialization in married couples in the 1970s and 1980s. Further, Badgett (1995b, 2001) suggests that because many employee benefits are accessible only to married couples, same-sex partners will face stronger incentives to both engage in market work. This suggests that the lack of access to marriage (and its associated legal property rights and responsibilities) may be partially responsible for lower levels of household specialization in lesbian households relative to married households.

${ }^{15}$ As stated, the majority of married women (81 percent) are identified as secondary earners using our identification strategy. If we limit the married sample to only secondary earners, the sexual orientation labor supply gap between married women and secondary lesbian earners is 517 annual hours and the gap between married women and primary lesbian earners is 992 annual hours.

${ }^{16}$ For example, 99 (5) percent and 90 (16) percent of primary lesbian earners and secondary lesbian earners participate in the labor market (work part-time), respectively (see Table 1 and Appendix Table 1, columns 3 and 4). For married men and women the percent participating in the labor market (working part-time) are 96 (3) and 79 (28) percent, respectively. Thus primary lesbian earners parallel married men while secondary earners parallel married women.
} 
supply finds a negative relationship between labor supply and the presence of children, particularly young children (see for example, Mroz 1987; Willis 1987; Browning 1992; Nakamura and Nakamura 1994). We therefore include two measures for children in the household: the number of children less than age six and the number of children ages 6-17. Only children denoted as related (biologically or through adoption or marriage) to one of the two partners in the household are included in the analysis. This restriction eliminates children living in the household who are not directly related to the married or lesbian partners, for instance grandchildren. ${ }^{17}$

Appendix Table 1 reveals that married women are more likely to have children in the household than their lesbian counterparts ( 66 percent vs. 21 percent). Both lesbian women and married women are more likely to have older children (6-17) in the household than younger children (less than 6), although the difference among lesbian households is much smaller. Specifically, the probability of having children less than six (6-17) in the household is 28 (52) and 9 (14) percent for married and lesbian women, respectively. Finally, on average married women have 0.4 children less than 6 and 0.9 children 6-17 while lesbian women have 0.1 children less than 6 and 0.2 children 6-17 (see Table 1). Interestingly, Appendix Table 1 shows that if lesbian women have children, then the number of children in the household is similar to that of married women (1.56 vs. 1.93$)$. This suggests that for lesbian couples relative to married couples, the difference is predominantly on the extensive margin of having children.

Thus there is evidence to support the notion that lesbian women have fewer children than their married counterparts. Is there also evidence to show that lesbian women adjust their labor supply by the presence of children? To investigate this, Table 2 presents annual hours of work

\footnotetext{
${ }^{17}$ This restriction uses family relationship variables constructed in the IPUMS data. Our results are robust to including all children in the household, regardless of relationship to the household head and their spouse or partner, and are available upon request.
} 
by presence of children, sexual orientation, and earner status. Consistent with the married women's labor supply literature, we find that married women with children work fewer annual hours (1228) than married women without children (1618). A similar pattern is found for secondary lesbian earners. Secondary lesbian earners with children work 257 fewer annual hours relative to their secondary lesbian counterparts without children. For primary lesbians earners we find little evidence of an effect of children on their labor supply (i.e., annual hours drop by 96 hours per year). These results for primary lesbian earners are more in line with the results found for married men, although married men tend to have higher labor supply with the presence of children.

Table 2 also presents conditional annual hours of work and labor force attachment by presence of children, sexual orientation and earner status. The difference in conditional annual hours (labor force attachment) between women without children and women with children (that is, the motherhood gap) is 286 (9), 120 (3), 168 (6), and 88 (0.5) hours per year (percentage points) for married women, all lesbian women, secondary lesbian earners, and primary lesbian earners, respectively. These results suggest that the intensive margin is more important than the extensive margin for the motherhood gap in annual hours. To test this formally we apply equation (3) to the motherhood gap in annual hours (i.e., subscript L now refers to women without children and subscript $\mathrm{M}$ now refers to women with children). We do indeed find that more of the adjustment occurs on the intensive margin rather than the extensive margin for the motherhood gap in annual hours, irrespective of sexual orientation and earner status. There are, however, some interesting differences within groups. For married women the intensive margin explains 55 percent of the motherhood gap in annual hours, while for the combined lesbian sample, secondary lesbian earners, and primary lesbian earners the intensive margin explains 63 , 
56, and 89 percent, respectively. These patterns provide further support for the specialization hypothesis as primary lesbian workers are much less likely than secondary lesbian earners (who mirror married women) to exit the labor force with the presence of children.

The literature on married women's labor supply also points to the importance of controlling for wages (own and spousal), as well as non-labor income. In general, higher levels of own wages lead to an increase in married women's labor supply (substitution effect dominates income effect) while higher spousal wages and non-wage income lead to a decrease in married women's labor supply (pure income effect). For married men, the patterns differ, higher levels of own wages lead to an increase in their labor supply but they are generally unresponsive to spousal wages and non-labor income. These patterns are consistent with the traditional division of labor in the household, and further reinforce the importance of accounting for household specialization when considering lesbian couple's labor supply decisions.

Non-labor income includes investment income (interest, dividend, and rental income), retirement income, social security income, welfare (public assistance) income, supplementary security income (SSI), and other income. ${ }^{18}$ We calculate hourly wages as earnings (wage and salary income) divided by conditional annual hours of work. We then take the natural log of hourly wages. We further restrict allowable log hourly wage observations to include only respondents who earn between $\$ 2 /$ hour and $\$ 100 /$ hour, do not have an allocation flag on earnings, and work for wages and salary either in the private sector (including non-profit) or the public sector (federal, state, or local government). For all individuals (i.e., non-workers, respondents with invalid wage observations or imputed wages, self-employed, and unpaid family

\footnotetext{
$18 \mathrm{We}$ considered an alternative specification that excluded social security income, welfare income, and supplementary security income as one could argue that these income sources may influence an individual's labor supply decisions differently than the other non-labor income sources. The results, however, were substantively the same and are available upon request.
} 
workers) for whom we do not have a valid log hourly wage observation, we impute wages using a regression approach similar to that used by Blau and Kahn $(2005 ; 2007)$. We run log hourly wage regressions by gender, sexual orientation, and low or high weeks worked (less than 20 weeks and 20 or more weeks last year). Our control variables include age and age squared (own and partner's), education (own and partner's), region, and a metropolitan status indicator (see below for variable definitions). For non-workers we impute wages based on those who work less than 20 weeks in the last year while for all other workers with invalid wages (respondents with invalid wages observations or imputed wages, self-employed, and unpaid family workers) we impute wages based on their actual weeks of work.

Consistent with previous research (Klawitter and Flatt 1998; Clain and Leppel 2001; Berg and Lien 2002; Black et al. 2003; Blandford 2003; Antecol, Jong and Steinberger 2008), Table 1 shows that married women earn less than their lesbian couple counterparts (2.539 vs. 2.778). The earnings advantage enjoyed by lesbians relative to married women is narrowed (widened) for secondary (primary) lesbian earners. Partner wages are higher for married women relative to the combined sample of lesbian women, although the gap between partner's wages is only $1.3 \log$ points between secondary lesbian earners and married women. This is consistent with other studies (e.g., Antecol, Jong, and Steinberger 2008) which find that married male earnings are higher than the earnings of any other group by sexual orientation (i.e., gay males, heterosexual cohabiting males, lesbian women, and married women). Finally, non-labor income is higher among lesbian couples than among married couples (\$4851 vs. \$4403). ${ }^{19}$ Interestingly, investment income is driving this difference and not other forms of non-labor income, suggesting

\footnotetext{
${ }^{19}$ The average household non-labor income values vary by earner status in the lesbian sample due to weighting, that is, the census weights are individual specific not couple specific.
} 
that lesbian households have higher levels of financial assets than their married counterparts, perhaps as a result of their lower rates of home ownership (Romero, et al. 2007).

We include a number of additional demographic controls. We include 4 indicator variables for education, less than high school, high school (omitted category), some college and college graduate. Lesbian women are more likely to have a college degree than married women (See Appendix Table 1) or married men (not reported). Again, this is consistent with earlier findings (see for example, Black et al. 2003). In addition, primary lesbian earners are 9 percentage points more likely to have a college degree than secondary lesbian earners. We also include six indicator variables for age (25-29 (omitted category), 30-34, 35-39, 40-44, 45-49, 50$54)^{20}, 9$ regional indicator variables (New England, Middle Atlantic, East North Central, West North Central, South Atlantic, East South Central, West South Central, Mountain, and Pacific (omitted category)), and an indicator for metropolitan area (see Appendix Table 1 for descriptive statistics).

The importance of properly accounting for earner status when estimating the role of observable characteristics, and children in particular, in accounting for the gap in labor supply by sexual orientation is the focus of the remainder of the paper.

\section{Determinants of Labor Supply by Sexual Orientation and Earner Status}

Following the convention in the married women's labor supply literature, we estimate the following model of labor supply using ordinary least squares (OLS) and instrumental variables (IV) separately for married women, the combined lesbian sample, secondary lesbian earners and primary lesbian earners:

\footnotetext{
${ }^{20}$ We use a more flexible definition of age in the annual hours of work specification than in the wage imputation specification because, to the best of our knowledge, their does not exist a literature for married women documenting a concave relationship between labor supply and age whereas there is strong evidence to support a concave relationship between wages and age.
} 


$$
A H_{i}=\alpha_{0}+\alpha_{1} \ln W_{i}+\alpha_{2} \ln W_{i}^{P}+\alpha_{3} N_{i}+\beta X_{i}+\varepsilon_{i}
$$

where $\mathrm{AH}$ is annual hours of work, $\ln \mathrm{W}$ is own (natural) $\log$ hourly wage, $\ln \mathrm{W}^{\mathrm{P}}$ is partner (natural) $\log$ hourly wage, $\mathrm{N}$ is non-labor income/1000, $\mathrm{X}$ is a vector of observable characteristics (presence of children, education, age, region, and an indicator for metropolitan status), i represents an individual, and $\varepsilon$ is an error term with the usual properties.

Table 3 presents the ordinary least squares (Panel A) and instrumental variables (Panel B) results for annual hours of work. There are several noteworthy patterns. First, we find that women, irrespective of sexual orientation, decrease their annual hours of work with the presence of children (particularly young children); however the effects are much smaller in magnitude for lesbian women. For example, married women decrease their annual hours of work by 389 hours for each additional child under the age of 6 (column 1) while lesbian women decrease their annual hours of work by 144 hours for each additional child under the age of 6 (column 2). As previously noted, the results for all lesbian women are misleading as they do not take into account the household division of labor between market and household production. Specifically, secondary lesbian earners decrease their annual hours of work more for each additional child under the age of 6 (column 3; 194 hours) than primary lesbian earners (column 4; 88 hours). Interestingly, married men increase their annual hours of work by 33 hours per year for each additional child under the age of 6 and by 29 hours for each additional child between the ages of 6 to 17 (not reported). These patterns are consistent with the labor supply literature for married women (and married men) as well as with the summary statistics presented in Section II.

Second, we find that married women and lesbian women increase their annual hours of work with own log wage and decrease their annual hours of work with partner's log wage and 
non-labor income. ${ }^{21}$ As with the presence of children, the magnitude of the effects for log wages (own and partner) are much smaller for the lesbian sample. While non-labor income continues to be negatively correlated with annual hours regardless of earner status for lesbians, the effect of log wages (own and partner) does vary by earner status for lesbians. In particular, own and partner log wages are statistically insignificant for primary lesbian earners, whereas own log wage is negatively correlated with annual hours and partner log wage is positively associated with annual hours for secondary lesbian earners (see columns 3 and 4, Table 3). This is an artifact of how an individual is selected into the primary and secondary samples, that is, in order to be in the secondary earner sample a lesbian must have lower annual earnings than her partner. Annual earnings are comprised of hourly wages times annual hours of work. If own log hourly wages increase, and the secondary earner increased her annual hours, this would lead to a change in her earner status which we have not allowed for by definition. Similarly, as partner log wages rise, a lesbian with higher annual hours can remain in the secondary earner sample.

OLS estimates of annual hours based on equation 4 may suffer from division bias as, by construction, our measure of hourly wages is annual earnings divided by annual hours. A measurement error in work hours, therefore, would lead to a negative bias on the coefficient for own log hourly wages. Moreover, (own and partner) log hourly wages are potentially endogenous, as isolating the exogenous effects of wages from effects of unobserved individual characteristics (such as motivation) that are correlated with wage offers is difficult. This omitted variable bias implies $E\left(\varepsilon_{i} \mid \ln W_{i}\right) \neq 0$ and $E\left(\varepsilon_{i} \mid \ln W_{i}^{P}\right) \neq 0$ leading OLS regression models to produce biased estimates of the effects of (own and partner) log wages.

\footnotetext{
${ }^{21}$ Married women's annual hours of work (relative to 25-29 year olds) are constant up until 30-34 years of age, and then fall in higher age categories. For lesbian women annual hours do not vary by age except for small increases at 30-34 and 40-44 years of age. In terms of education, both married and lesbian women work less (more) for less than high school (some college and college graduate) relative to high school degree. Results for age, education, region and metropolitan status are available upon request.
} 
In an attempt to address the measurement error bias and omitted variable bias, we reestimate equation (1) using instrument variables (IV) analysis. As in many studies of labor supply (Angrist 1991; Blundell, Duncan, and Meghir 1998; Pencavel 1998; Devereux 2004; Blau and Kahn 2005; 2007), we instrument for (own and partner) log hourly wages using group averages. $^{22}$ Specifically, we take the average of (own and partner) log wages within 10 decile bins by gender and sexual orientation and assign each respondent the average according to their decile, gender and sexual orientation. The IV results are presented in Panel B of Table 3. It can be seen that the returns estimated under the IV approach are quantitatively similar to the OLS returns presented in Panel A of Table 3.

Another concern with the regression analysis is our inability to determine the causal effect of the number of children on labor supply because fertility decisions and labor supply decisions are likely jointly determined (Browning 1992). This endogeneity problem has been addressed in other studies with instrumental variables. ${ }^{23}$ These studies continue to find a negative relationship between fertility and labor supply, although the magnitude of the effect tends to be smaller. Unfortunately, we are unable to identify a reasonable instrument in our data that is correlated with our measures of fertility but uncorrelated with the error term in the labor supply equation. $^{24}$

Our inability to address the endogeneity of children in the regression estimates of labor supply, however, is not problematic in our main analysis (presented below) because our ultimate

\footnotetext{
${ }^{22}$ Unlike IV approach based on individual data, the grouped data approach does not require exclusion restrictions. However, the grouped data approach yields smaller effective sample sizes (see Blau and Kahn 2005 for a detailed discussion of the advantages and disadvantages of the two approaches).

${ }^{23}$ Lundberg and Rose (2002) use cohort analysis and fixed effects to determine the impact of effects of children and the differential effects of sons and daughters on men's labor supply (and hourly wage rates).

${ }^{24}$ While many instruments used are dubious based on theoretical grounds (Browning 1992), two classes of instruments are reasonable on both empirical and theoretical groups. These include parental preferences for mixed sibling-sex composition (e.g., Angrist and Evans 1998) and twinning at first birth (e.g., Bronars and Grogger 1994). We do not have large enough samples of lesbian women with more than two children or with multiple births at first birth to use either of these as instruments.
} 
goal is to determine the role observable characteristics, particularly children, play in explaining the sexual orientation gap in labor supply by earner status. Our primary purpose for presenting the OLS labor supply results was to place our findings in the broader context of the married women's (and men's) labor supply literature. The remainder of the paper focuses on a semiparametric decomposition approach which greatly reduces the endogeneity concerns associated with children and (own and partner) wages because it does not rely on imputed annual hours or estimate an error term.

\section{Semi-Parametric Decomposition Approach}

\section{IV.1 Mean Annual Hours}

To examine the explanatory power of observable characteristics, particularly children, in explaining the sexual orientation gap in annual hours, we adopt a DiNardo, Fortin and Lemieux (1996) (DFL) decomposition approach. The DFL technique constructs a counterfactual distribution of annual hours to estimate how differences in the distribution of observable characteristics contribute towards differences in the distribution of annual hours between married women and lesbian women by earner status. In other words, we create a distribution of annual hours for lesbian women if they had the same distribution of observable characteristics as married women.

The DFL approach is ideal for our purposes for a number of reasons. First, as previously stated, the DFL approach does not impute annual hours or estimate an error term. This is in sharp contrast to the Oaxaca-Blinder (1973) decomposition approach which imputes annual hours for lesbian women based on the estimated coefficients for married women. Given this, the Oaxaca-Blinder decomposition results may be biased if children and (own and partner) $\log$ hourly wages are endogenous, while the DFL decomposition results will remain unbiased even if 
children and wages are endogenous. Second, the DFL approach eliminates the division bias problem because the DFL approach does not rely on estimates from a regression where the dependent variable is annual hours and one of the independent variables is divided by annual hours (own log hourly wages). Finally, unlike the Oaxaca-Blinder decomposition approach which only decomposes at the mean, the DFL approach decomposes across the entire distribution of annual hours. This allows us to determine the role the extensive and intensive margins play in explaining the sexual orientation annual hours gap, and allows us to determine at what points in the distribution of annual hours women respond to the presence of children in the household.

The DFL is estimated in stages. In the first stage we isolate children from the other observable characteristics. This allows us to construct a counterfactual distribution of annual hours if lesbians had the same number of children as their observationally equivalent married counterparts. The DFL decomposition is extended sequentially for each additional covariate. ${ }^{25}$ For a more detailed description of the DFL decomposition see DiNardo, Fortin, and Lemieux (1996).

For computational ease in our analysis, we estimate each stage in the DFL as:

$$
\psi_{X n \mid X \neq n}\left(X_{i}\right)=\frac{\left(\frac{1-P\left(L \mid X_{n}, X_{\neq n}\right)}{P\left(L \mid X_{n}, X_{\neq n}\right)}\right)}{\left(\frac{1-P\left(L \mid X_{\neq n}\right)}{P\left(L \mid X_{\neq n}\right)}\right)}
$$

where $\mathrm{L}$ represents membership in the lesbian sample (all, secondary earners or primary earners), $X_{n}$ are the set of observable characteristics (in order: presence of children, own log wage, partner

\footnotetext{
${ }^{25}$ The sequential DFL is somewhat sensitive to the order in which individual characteristics are selected for decomposition. While the total effect of controlling for all characteristics will be the same, a single characteristic's estimated influence on the counterfactual distribution of annual hours tends to be larger the later it is accounted for in the sequential DFL. Our main findings concerning the relative role of children are generally robust to the ordering of the sequential DFL. Our preferred ordering, which accounts for children first, gives a conservative estimate of the relative influence of children on the counterfactual distribution of annual hours.
} 
log wage, non-labor income, education, age, an indicator for metropolitan status, and region) conditionally controlled in that stage of the DFL, $X_{\neq n}$ are the remaining covariates and $\psi_{X n \mid X \neq n}\left(X_{i}\right)$ is the reweighting function defining a unique weighting factor for each observation based on that person's unique set of observable characteristics. The contribution of each characteristic is then defined as the reduction in the annual hours gap when that characteristic is sequentially included in $X_{n}$. We estimate the reweighting factor at each stage using two logistic estimates. $^{26}$

Due to the lack of lesbian households with large numbers of children, including linear variables for the presence of children (i.e., the number of children less than 6 and the number of children 6-17) in equation 5 would lead the few households in the lesbian sample with large numbers of children to receive reweighting factors that are unrealistically large. ${ }^{27}$ Therefore, to reduce the restrictiveness of our estimation procedure and ensure reasonable reweighting factors when estimating the DFL, the variables associated with the presence of children in the household are coded as eight mutually exclusive dummy variables. ${ }^{28}$ To further reduce the restrictiveness

\footnotetext{
${ }^{26}$ Alternatively, the reweighting factor at each stage can be estimated as the product of several consecutive multinomial logistic estimates (see Antecol, Jong and Steinberger 2008 for a detailed explanation of this alternative estimation strategy). Similar results are found using either strategy and are available upon request.

${ }^{27}$ If the presence of children in the home is included as linear variables in the DFL, as it is in the OLS and IV in Section III, then children are incorrectly estimated to explain 150 to 250 percent of the actual sexual orientation annual hours gap.

${ }^{28}$ The eight categories include: no children present, one child 6-17, two or more children $6-17$, one child less than 6 , two or more children less than 6 , one child less than 6 and one 6-17, one child less than 6 and two or more children 6-17, and two or more children less than 6 and one or more children 6-17. We employed several other categorical divisions of the presence of children in the household all of which give similar results and are available upon request.
} 
of our DFL estimation strategy, own log wage, partner log wage and non-labor income are also included as categorical variables rather than continuous linear variables. ${ }^{29}$

The results for the DFL decomposition evaluated at the mean of annual hours are presented in Table 4. The total gap in annual hours between secondary lesbian earners and married women is 352 hours while the total gap in annual hours between primary lesbian earners and married women is 826 hours. Given the importance of accounting for household specialization, not surprisingly the total gap in annual hours between the combined sample of lesbian women and married women lies within these two extremes, i.e., 589 hours per year.

Observable (unobservable) characteristics account for 211 (141) hours of the sexual orientation gap in annual hours for secondary lesbian earners, or 60 (40) percent of the total gap. For primary lesbian earners, observable (unobservable) characteristics account for only 126 (701) hours of the sexual orientation gap in annual hours, or 15 (85) percent of the total gap. Breaking up the portion of the gap attributable to differences in observable characteristics into the extensive and intensive margin reveals that the extensive margin plays a larger role for secondary lesbian earners (132 hours, 63 percent of the explained gap) than for primary lesbian earners (36 hours, 29 percent of the explained gap). ${ }^{30}$

If secondary (primary) lesbian earners had the same number of children as their observationally equivalent married counterparts then the sexual orientation gap in annual hours would fall to 158 (751) hours per year because secondary (primary) lesbian earners would work

\footnotetext{
${ }^{29}$ Own log wage is included as ten dummy variables representing deciles in the married female log wage distribution, partner log wage is included as five dummy variables denoting quintiles of the partner log wage distribution for married women, and non-labor income is included as five dummy variables (less than zero, zero, $\$ 1$ to $\$ 10,000, \$ 10,001$ to $\$ 50,000$, and over $\$ 50,000$ of income). Substantive results do not vary when these variables are included in the DFL analysis as continuous variables, but the reweighting factors for some observations with very high or very low values of own log wage, partner log wage and non-labor income are more extreme when these variables are included linearly. Results are available upon request.

${ }^{30}$ We again apply equation (3) to explore the role of the extensive and intensive margins. Specifically, subscript L now refers to the actual annual hours of the lesbian sample and subscript $\mathrm{M}$ now refers to the counterfactual annual hours of the lesbian sample with the distribution of observable characteristics equal to the married sample.
} 
194 (76) hours less per year. In other words, the presence of children (conditional on all other observable characteristics) explains 55 (9) percent of the total gap in annual hours between secondary (primary) lesbian earners and married women. In addition, the role of children on the decision to remain in the labor force (the extensive margin) plays a larger role for secondary lesbian earners (91 hours, 26 percent of the total gap) than for primary lesbian earners (20 hours, 2 percent of the total gap). The remaining characteristics (own log wage, partner log wage, nonlabor income, age, metropolitan area, and region) do not play a significant role in explaining the higher levels of labor supply of lesbian women. ${ }^{31}$

These results provide strong support for controlling for the division of labor between household and market production within lesbian households. When specialization is taken into account, we find that secondary lesbian earners are more closely aligned with married women with respect to the number of annual hours they work. Secondary lesbian earners also have a much larger labor supply response when they are assigned married women's distribution of children (conditional on all other observable characteristics) than do primary lesbian earners, including a much larger response along the extensive margin. This suggests, that like married women, secondary lesbian earners may be the primary caregivers to the household's children and likely substitute between market work, household work, and leisure when making their labor supply decisions, while primary lesbian earners (like married men) likely substitute primarily between market work and leisure (Mincer 1962).

Given the importance of the specialization hypothesis, casual empiricism suggests that the effect of controlling for the presence of children will not be uniform along distribution of

\footnotetext{
${ }^{31}$ We find similar results if we limit the married women sample to only include secondary earners. In particular, performing a separate DFL analysis on this sample shows observable characteristics explain 38 (23) percent of the gap in annual hours between married women and secondary (primary) lesbian earners. The presence of children (conditional on all other observable characteristics) explains 38 (10) percent of the total gap in annual hours between secondary (primary) lesbian earners and married women.
} 
conditional annual hours (intensive margin). Thus, the next section formally analyzes the distribution of conditional annual hours. For completeness, we also directly examine the effect of children on the sexual orientation gap in labor force attachment (extensive margin).

\section{IV.2 Labor Force Attachment and the Distribution of Conditional Annual Hours}

Focusing first on labor force attachment (i.e., working a positive number of annual hours), Table 5 reveals that primary lesbian women have the highest labor force attachment (99 percent), followed by secondary lesbian women (90 percent), and married women (79 percent). What can account for these differences? Using the DFL reweighting factors from equation 5, we decompose the mean sexual orientation gap in labor force attachment (see Panel A Table 6). As was the case for the sexual orientation gap in annual hours, observable characteristics account for a much larger share of the sexual orientation gap in labor force attachment between secondary lesbian earners and married women (63 percent) than between primary lesbian earners and married women ( 8 percent). Moreover, children are the most important observable characteristic, and account for 43 (5) percent of the gap in labor force attachment between secondary (primary) lesbian earners and married women.

We now turn to conditional annual hours. In order to analyze the distribution of conditional annual hours, we construct three indicator variables for individuals with positive annual hours of work. Full attachment equals one if the worker has annual hours between 1750 and 2080, and zero otherwise. ${ }^{32}$ Less than full attachment equals one if the worker has moderate annual hours (between 1 and 1749), and zero otherwise. Finally, greater than full attachment equals one if the worker has extremely high annual hours (2081 or more), and zero otherwise.

\footnotetext{
${ }^{32}$ These annual hours cutoffs are selected to represent the number of annual hours associated with full time full year employment; 35 usual hours per week times 50 weeks per year equals 1750 annual hours and 40 usual hours per week times 52 weeks per year equals 2080 annual hours. Results are generally robust to other annual hour cutoffs for full attachment.
} 
Table 5 shows that primary lesbian earners are more likely to work extremely high annual hours (43 percent) than secondary lesbian earners (27 percent) or married women (18 percent). There is very little difference in the probability of being fully attached by sexual orientation. Given these three indicators by definition have to sum to one, married women have the highest incidence (39 percent) of less than full attachment, followed by secondary lesbian earners (29 percent) and primary lesbian earners (11 percent).

In order to determine how children impact the distribution of conditional annual hours, we again use the DFL reweighting factors to decompose the sexual orientation gap in the probability of less than full attachment, full attachment, and greater than full attachment (see Panel B of Table 6). As expected, the effect of children is not uniform along the distribution of conditional annual hours. Specifically, children play a significant role in explaining the higher incidence of lesbian workers working extremely high annual hours relative to working married women, and the effect for secondary lesbian earners is much larger than for primary lesbian earners. Controlling for the presence of children reduces the gap in the probability of working extremely high annual hours by 5 (6) percentage points or 58 (24) percent of the total gap for secondary (primary) lesbian earners. Interestingly, accounting for differences in characteristics results in nearly no change in the percentage of secondary lesbian earners who are fully attached, indicating changes along the intensive margin disproportionately affect secondary lesbian earners' decision to work extremely high annual hours.

\section{Conclusion}

We formally analyze the role of observable characteristics, particularly children, in explaining differences in labor supply between married women and partnered lesbians. We argue, however, that simply combining all partnered lesbians into a single group (as is currently 
done in the limited sexual orientation labor supply literature) will lead to biased results because, like married heterosexual couples, lesbian couples are comprised of primary and secondary earners. Both couple types face incentives to divide labor between primary and secondary earners because there are increasing returns from investments in specific human capital in market and household work which need not be based on gender, and hence the secondary earner in each household who specializes in household production will earn less than their partner (Becker 1981; 1985). To account for this, we identify earner status in lesbian households based on yearly earnings.

Using 2000 U.S. Census data we first illustrate that it is not advisable to ignore household specialization in partnered lesbian households. In particular, primary lesbian earners work 475 more unconditional annual hours per year than their secondary lesbian counterparts and are also more likely to be attached to the labor market and work extremely high annual hours (2081 hours or more). Not surprisingly, relative to the combined lesbian sample, secondary lesbian earners have labor supply measures significantly closer to married women (predominately secondary earners) while primary lesbian earners have labor supply measures significantly closer to married men (predominantly primary earners). Moreover, we find differential effects of observed characteristics, particularly the presence of children, on the labor supply decisions of primary and secondary lesbian earners that are comparable with those found in the married men's and women's labor supply literature.

Secondly, we formally analyze the determinants of the mean sexual orientation gap in unconditional annual hours by earner status using a semi-parametric decomposition approach. As predicted, we find children explain 55 (9) percent of the mean gap in unconditional annual hours between secondary (primary) lesbian earners and married women. Moreover, all 
observable characteristics (including children) account for 59 percent of the mean labor supply gap between married women and secondary lesbian earners, but only 15 percent of the gap between married women and primary lesbian earners. Finally, we illustrate that controlling for children significantly reduces differences between married women and secondary lesbian earners both in terms of the decision to remain attached to the labor market (the extensive margin), as well as in terms of annual hours of work conditional on working (the intensive margin). The effect of controlling for children however is not uniform across the distribution of conditional annual hours; instead it primarily reduces the percentage of secondary lesbian earners working extremely high annual hours.

One of the main innovations of this paper is our identification of household specialization in partnered lesbian households. While we use this strategy to examine the determinants of the sexual orientation gap in labor supply, it could also prove to be very important in a number of additional applications in the sexual orientation literature, including (but not limited to) the sexual orientation wage gap ${ }^{33}$ and household bargaining in same-sex partnered households.

\footnotetext{
${ }^{33}$ While it has been posited that the wage penalty (advantage) of gays (lesbians) is due to the differential investment in human capital associated with household specialization theories (Badgett 2001; Black et al. 2003; Black, Sanders, and Taylor 2007), this hypothesis has not been formally tested in the sexual orientation wage gap literature.
} 


\section{References}

Angrist, Joshua D. 1991. "Grouped-Data Estimation and Testing in Simple Labor-Supply Models."Journal of Econometrics, Vol. 47, Issue 2-3 (February), pp. 243-266.

Angrist, Joshua D., and William N. Evans. 1998. "Children and Their Parents' Labor Supply: Evidence from Exogenous Variation in Family Size." American Economic Review, Vol. 88, No. 3 (June), pp. 450-477.

Antecol, Heather, Anneke Jong and Michael D. Steinberger. 2008. "The Sexual Orientation Wage Gap: The Role of Occupational Sorting and Human Capital." Industrial and Labor Relations Review, Vol. 61, No. 4 (July), pp. 518-543.

Badgett, M.V. Lee. 1995a. "The Wage Effects of Sexual Orientation Discrimination.” Industrial and Labor Relations Review, Vol. 48, No. 4 (July), pp. 726-39.

Badgett, M.V. Lee. 1995b. "Gender, Sexuality and Sexual Orientation: All in the Feminist Family?” Feminist Economics, Vol. 1, No. 1 (January), pp. 121-139.

Badgett, M.V. Lee. 2001. Money, Myths, and Change: The Economic Lives of Lesbians and Gay Men, University of Chicago Press, Chicago, Illinois.

Bardasi, Elena, and Mark Philip Taylor. 2008. "Marriage and Wages: A Test of the Specialization Hypothesis.” Economica, Vol. 75, Issue 299 (August), pp. 569-591.

Becker, Gary. 1981. A Treatise on the Family. Harvard University Press, Cambridge, Massachusetts.

Becker, Gary. 1985. "Human Capital, Effort, and the Sexual Division of Labor." Journal of Labor Economics, Vol. 3, No. 1(January), pp. S33-S58.

Berg, Nathan, and Donald Lien. 2002. "Measuring the Effect of Sexual Orientation on Income: Evidence of Discrimination?" Contemporary Economic Policy, Vol. 20, No. 4 (October), pp. 394-414.

Bianchi, Suzanne M., John P. Robinson, and Melissa A. Milkie. 2006. Changing Rhythms of American Family Life. American Sociological Association's Rose Series. Russell Sage, New York.

Bielby, William T., and Denise D. Bielby. 1989. "Family Ties: Balancing Commitments to Work and Family in Dual Earner Households." American Sociological Review, Vol. 54, No. 5 (October), pp. 776-789.

Black, Dan, Gary Gates, Seth Sanders and Lowell Taylor. 2002. "Same-Sex Unmarried Partner Couples in Census 2000: How Many are Gay and Lesbian?" Unpublished paper, Syracuse University. 
Black, Dan, Hoda Makar, Seth Sanders and Lowell Taylor. 2003. "The Earnings Effects of Sexual Orientation." Industrial and Labor Relations Review, Vol. 56, No. 3 (April), pp. 449-469.

Black, Dan A., Seth G. Sanders, and Lowell J. Taylor. 2007. "The Economics of Lesbian and Gay Families.” Journal of Economic Perspectives, Vol. 21, No. 2 (Spring), pp. 53-70.

Blandford, John M. 2003. "The Nexus of Sexual Orientation and Gender in the Determination of Earnings.” Industrial and Labor Relations Review, Vol. 56, No. 4 (July), pp. 622-642.

Blau, Francine D. and Lawrence M. Kahn. 2005. "Changes in the Labor Supply Behavior of Married Women: 1980-2000.” NBER Working Paper No. 11230, March.

Blau, Francine D. and Lawrence M. Kahn. 2007. "Changes in the Labor Supply Behavior of Married Women: 1980-2000.” Journal of Labor Economics, Vol. 25, No. 3 (July), pp. 393-437.

Blinder, Alan S. 1973. "Wage Discrimination: Reduced Form and Structural Estimates." Journal of Human Resources, Vol. 8, No. 4 (Autumn), pp. 436-455.

Blundell, Richard, Alan Duncan, and Costas Meghir. 1998. "Estimating Labor Supply Responses Using Tax Reforms.” Econometrica, Vol. 66, Issue 4 (July), pp. 827-861.

Blundell, Richard, and Thomas MaCurdy. 1999. "Labor Supply: A Review of Alternative Approaches." Handbook of Labor Economics, Volume 3A, pp. 1559-1695.

Bronars, Stephen G. and Jeff Grogger. 1994. "The Economic Consequences of Unwed Motherhood: Using Twin Births as a Natural Experiment." American Economic Review, Vol. 84, No. 5 (December), pp. 1141-1156.

Browning, Martin. 1992. "Children and Household Economic Behavior." Journal of Economic Literature, Vol. 30, No. 3(September), pp. 1434-1475.

Carrington, Christopher. 1999. No Place Like Home: Relationships and Family Life among Lesbians and Gay Men. The University of Chicago Press, Chicago, Illinois.

Clain, Suzanne Heller and Karen Leppel. 2001. "An Investigation into Sexual Orientation Discrimination as an Explanation for Wage Differences." Applied Economics, Vol. 33, Issue 1 (January), pp. 37-47.

Daniel, Kermit. 1992. "Does marriage make men more productive?" University of Chicago Population Research Center Discussion Paper Series 92-2, March.

Devereux, Paul J. 2004. "Changes in Relative Wages and Family Labor Supply." Journal of Human Resources, Vol. 39, No. 3 (Summer), pp. 696-722. 
DiNardo, John, Nicole Fortin and Thomas Lemieux. 1996. "Labor Market Institutions and the Distribution of Wages, 1973-1992 : A Semiparametric Analysis." Econometrica, Vol. 64, No. 5 (September), pp. 1001-1044.

Drago, Robert and Ya-Ning Lee. 2008a. "The Parenting of Infants: A Time Use Study." Pennsylvania State University Population Research Institute Working Paper Series No. 08-02, May.

Drago, Robert and Ya-Ning Lee. 2008b. "What Would They Do? Childcare under Parental Leave and Reduced Hours Options." Pennsylvania State University Population Research Institute Working Paper Series No. 08-03, June.

Gray, Jeffrey S. 1997. "The Fall in Men's Return to Marriage: Declining Productivity Effects or Changing Selection?” Journal of Human Resources, Vol. 32, No. 3 (Summer), pp. 481-504.

Hersch, Joni and Leslie S. Stratton. 2000. "Household Specialization and the Male Marriage Wage Premium.” Industrial and Labor Relations Review, Vol. 54, No. 1 (October), pp. 78-94.

Kalenkoski, Charlene, David Ribar and Leslie S. Stratton. 2005. "Parental Child Care in Single Parent, Cohabiting, and Married Couple Families: Time Diary Evidence from the United Kingdom." American Economic Review, Papers and Proceedings, Vol. 95, No. 2 (May), pp. 194-198.

Kalenkoski, Charlene, David Ribar and Leslie S. Stratton. 2007. "The Effect of Family Structure on Parents' Child Care Time in the United States and the United Kingdom." Review of Economics of the Household, Vol. 5, No. 4 (December), pp. 353-384.

Kenny, Lawrence W. 1983. "The Accumulation of Human Capital during Marriage by Males." Economic Inquiry, Vol. 21, No. 2 (April), pp. 223-231.

Klawitter, Marieka M. and Victor Flatt. 1998. "The Effects of State and Local Antidiscrimination Policies on Earnings for Gays and Lesbians." Journal of Policy Analysis and Management, Vol. 17, No. 4 (Autumn), pp. 658-686.

Leppel, Karen. 2008. "Labour Force Status and Sexual Orientation." Economica, Vol. 76, Issue 301 (February), pp. 197-207.

Loh, Eng Seng. 1996. "Productivity Differences and the Marriage Wage Premium for White Males.” Journal of Human Resources, Vol. 31, No. 3 (Summer), pp. 566-589.

Lundberg, Shelly, Sabrina Wulff Pabilonia and Jennifer Ward-Batts. 2007. "Time Allocation of Parents and Investments in Sons and Daughters." Working Paper, April.

Lundberg, Shelly, and Elaina Rose. 2002. "The Effects Of Sons And Daughters On Men's Labor Supply And Wages." The Review of Economics and Statistics, Vol. 84, No. 2 (May), pp. 251268. 
Mincer, Jacob. 1962. "Labor Force Participation of Married Women." In H. Gregg Lewis, ed., Aspects of Labor Economics, Universities National Bureau of Economic Research Conference Series, no. 14 (Princeton, NJ: Princeton University Press), pp. 63-97.

Mroz, Thomas A. 1987. "The Sensitivity of an Empirical Model of Married Women's Hours of Work to Economic and Statistical Assumptions." Econometrica, Vol. 55, No. 4 (July), pp. $765-$ 799.

Nakamura, Alice and Masao Nakamura. 1994. "Predicting Female Labor Supply: Effects of Children and Recent Work Experience." The Journal of Human Resources, Vol. 29, No. 2 (Spring), Special Issue: Women's Work, Wages, and Well-Being, pp. 304-327

Oaxaca, Ronald. 1973. "Male-Female Wage Differentials in Urban Labor Markets." International Economic Review, Vol. 14, No. 3 (October), pp. 693-709.

Pencavel, John. 1998. "The Market Work Behavior and Wages of Women." Journal of Human Resources, Vol. 33, No. 4 (Autumn), pp. 771-804.

Peplau, Letitia Anne and Adam W. Fingerhut. 2007. "The Close Relationships of Lesbians and Gay Men.” Annual Review of Psychology, Vol. 58, pp. 405-424.

Romero, Adam, Amanda Baumle, M.V. Lee Badgett and Gary Gates. 2007. "Census Snapshot: United States." The Williams Institute, Los Angeles, CA, (December).

Ruggles, Steven, Matthew Sobek, Trent Alexander, Catherine A. Fitch, Ronald Goeken, Patricia Kelly Hall, Miriam King, and Chad Ronnander. 2004. Integrated Public Use Microdata Series: Version 3.0 (machine-readable database). Minneapolis, Minn.: Minnesota Population Center (producer and distributor). Available at http://usa.ipums.org/usa/.

Stevenson, Betsey. 2007. "The Impact of Divorce Laws on Marriage-Specific Capital." Journal of Labor Economics, Vol. 25, No. 1 (January), pp. 75-94.

Stratton, Leslie S. 2002. "Examining the Wage Differential for Married and Cohabiting Men." Economic Inquiry, Vol. 40, No. 2 (April), pp. 199-212.

Tebaldi, Edinaldo and Bruce Elmslie. 2006. "Sexual Orientation and Labour Supply." Applied Economics, Vol. 38, No. 5 (March), pp. 549-562.

Willis, Robert J. 1987. "What Have We Learned from the Economics of the Family?" American Economic Review, Vol. 77, No. 2 (May), pp. 68-81. 
Table 1. Annual Hours, Labor Force Attachment, Children, Wage and Non-Labor Income by Sexual Orientation and Earner Status

\begin{tabular}{|c|c|c|c|c|}
\hline & $\begin{array}{c}\text { Married Women } \\
\text { (1) }\end{array}$ & $\begin{array}{c}\text { Lesbian } \\
\text { (2) }\end{array}$ & $\begin{array}{c}\text { Secondary Earner } \\
\text { Lesbian } \\
\text { (3) }\end{array}$ & $\begin{array}{c}\text { Primary Earner } \\
\text { Lesbian } \\
\text { (4) }\end{array}$ \\
\hline Annual Hours & $\begin{array}{l}1360.010 \\
(955.198)\end{array}$ & $\begin{array}{l}\mathbf{1 9 4 8 . 7 6 5} \\
(772.091)\end{array}$ & $\begin{array}{l}\mathbf{1 7 1 1 . 8 1 9} \\
(852.708)\end{array}$ & $\begin{array}{l}2186.347 \\
(593.461)\end{array}$ \\
\hline Annual Hours Gap & & 588.755 & 351.809 & 826.337 \\
\hline Usual Weekly Hours & $\begin{array}{l}28.980 \\
(18.300)\end{array}$ & $\begin{array}{l}39.997 \\
(13.627)\end{array}$ & $\begin{array}{l}36.172 \\
(15.415)\end{array}$ & $\begin{array}{l}43.832 \\
(10.213)\end{array}$ \\
\hline Weeks Last Year & $\begin{array}{l}36.047 \\
(21.447)\end{array}$ & $\begin{array}{l}\mathbf{4 5 . 4 7 4} \\
(14.183)\end{array}$ & $\begin{array}{l}41.884 \\
(17.423)\end{array}$ & $\begin{array}{l}\mathbf{4 9 . 0 7 3} \\
(8.525)\end{array}$ \\
\hline Labor Force Attachment & $\begin{array}{c}0.787 \\
(0.409)\end{array}$ & $\begin{array}{c}\mathbf{0 . 9 4 2} \\
(0.233)\end{array}$ & $\begin{array}{c}\mathbf{0 . 8 9 8} \\
(0.303)\end{array}$ & $\begin{array}{c}\mathbf{0 . 9 8 7} \\
(0.114)\end{array}$ \\
\hline Conditional Annual Hours & $\begin{array}{l}1727.573 \\
(723.878)\end{array}$ & $\begin{array}{r}2068.377 \\
(620.706)\end{array}$ & $\begin{array}{l}1906.943 \\
(661.667)\end{array}$ & $\begin{array}{l}2215.627 \\
(540.388)\end{array}$ \\
\hline Children in the Household & & & & \\
\hline Number of Children $<6$ & $\begin{array}{l}0.389 \\
(0.691)\end{array}$ & $\begin{array}{l}\mathbf{0 . 1 0 7} \\
(0.375)\end{array}$ & $\begin{array}{c}\mathbf{0 . 1 0 7} \\
(0.375)\end{array}$ & $\begin{array}{c}\mathbf{0 . 1 0 7} \\
(0.376)\end{array}$ \\
\hline Number of Children 6-17 & $\begin{array}{l}0.889 \\
(1.042)\end{array}$ & $\begin{array}{l}\mathbf{0 . 2 1 3} \\
(0.601)\end{array}$ & $\begin{array}{c}\mathbf{0 . 2 1 2} \\
(0.601)\end{array}$ & $\begin{array}{c}\mathbf{0 . 2 1 4} \\
(0.601)\end{array}$ \\
\hline Log Hourly Wage & $\begin{array}{c}2.539 \\
(0.489)\end{array}$ & $\begin{array}{c}2.778 \\
(0.508)\end{array}$ & $\begin{array}{c}2.637 \\
(0.497)\end{array}$ & $\begin{array}{c}2.918 \\
(0.479)\end{array}$ \\
\hline Partner's Log Hourly Wage & $\begin{array}{l}2.932 \\
(0.469)\end{array}$ & $\begin{array}{l}2.778 \\
(0.508)\end{array}$ & $\begin{array}{l}2.919 \\
(0.478)\end{array}$ & $\begin{array}{l}2.638 \\
(0.498)\end{array}$ \\
\hline Family Non-Labor Income & $\begin{array}{c}4403.062 \\
(17038.600)\end{array}$ & $\begin{array}{c}4851.247 \\
(17152.090)\end{array}$ & $\begin{array}{c}4806.718 \\
(17019.550)\end{array}$ & $\begin{array}{c}4895.895 \\
(17286.470)\end{array}$ \\
\hline $\begin{array}{l}\text { Observations } \\
\text { Obs. with Annual Hours }>0\end{array}$ & $\begin{array}{l}965469 \\
761541\end{array}$ & $\begin{array}{l}6502 \\
6118\end{array}$ & $\begin{array}{l}3251 \\
2908\end{array}$ & $\begin{array}{l}3251 \\
3210\end{array}$ \\
\hline
\end{tabular}

Notes: Means with standard errors in parentheses. Observations are weighted by the appropriate Census sampling weight. Annual hours, usual weekly hours and weeks last year include zero values. Labor force attachment equals one if annual hours are greater than zero. Conditional annual hours include only positive values for annual hours. The annual hours gap is calculated as the lesbian subsample average minus the married average. To facilitate comparisons between sexual orientation groups, bolded values in columns 2-4 represent a statistically significant difference in means at the 5 percent level relative to column 1 . 
Table 2. Annual Hours by Presence of Children in the Household, Sexual Orientation, and Earner Status

\begin{tabular}{|c|c|c|c|c|}
\hline & $\begin{array}{c}\text { Married Women } \\
\text { (1) }\end{array}$ & $\begin{array}{l}\text { Lesbian } \\
\text { (2) }\end{array}$ & $\begin{array}{c}\text { Secondary Earner } \\
\text { Lesbian } \\
\text { (3) }\end{array}$ & $\begin{array}{c}\text { Primary Earner } \\
\text { Lesbian } \\
\text { (4) }\end{array}$ \\
\hline \multicolumn{5}{|l|}{ Without Children } \\
\hline Annual Hours & $\begin{array}{l}1617.995 \\
(909.518)\end{array}$ & $\begin{array}{l}1984.764 \\
(749.628)\end{array}$ & $\begin{array}{l}1764.274 \\
(833.613)\end{array}$ & $\begin{array}{l}2206.154 \\
(575.138)\end{array}$ \\
\hline Labor Force Attachment & $\begin{array}{l}0.847 \\
(0.360)\end{array}$ & $\begin{array}{l}0.949 \\
(0.221)\end{array}$ & $\begin{array}{l}0.910 \\
(0.287)\end{array}$ & $\begin{array}{l}0.988 \\
(0.110)\end{array}$ \\
\hline Conditional Annual Hours & $\begin{array}{l}1909.170 \\
(648.219)\end{array}$ & $\begin{array}{r}2092.252 \\
(606.170)\end{array}$ & $\begin{array}{l}1939.447 \\
(651.194)\end{array}$ & $\begin{array}{l}2233.557 \\
(523.127)\end{array}$ \\
\hline Observations & 331108 & 5108 & 2554 & 2554 \\
\hline Obs. with Annual Hours $>0$ & 279166 & 4845 & 2320 & 2525 \\
\hline \multicolumn{5}{|l|}{ With Children } \\
\hline Annual Hours & $\begin{array}{l}\mathbf{1 2 2 7 . 6 2 2} \\
(951.017)\end{array}$ & $\begin{array}{l}\mathbf{1 8 0 8 . 9 8 9} \\
(839.501)\end{array}$ & $\begin{array}{l}\mathbf{1 5 0 7 . 4 5 4} \\
(895.091)\end{array}$ & $\begin{array}{l}2109.701 \\
(654.407)\end{array}$ \\
\hline Labor Force Attachment & $\begin{array}{l}\mathbf{0 . 7 5 6} \\
(0.429)\end{array}$ & $\begin{array}{l}\mathbf{0 . 9 1 7} \\
(0.276)\end{array}$ & $\begin{array}{l}\mathbf{0 . 8 5 1} \\
(0.356)\end{array}$ & $\begin{array}{l}0.983 \\
(0.129)\end{array}$ \\
\hline Conditional Annual Hours & $\begin{array}{l}1623.152 \\
(744.196)\end{array}$ & $\begin{array}{l}1972.488 \\
(667.652)\end{array}$ & $\begin{array}{l}\mathbf{1 7 7 1 . 5 6 2} \\
(687.843)\end{array}$ & $\begin{array}{l}2145.921 \\
(598.141)\end{array}$ \\
\hline Observations & 634361 & 1394 & 697 & 697 \\
\hline Obs. with Annual Hours $>0$ & 482375 & 1273 & 588 & 685 \\
\hline
\end{tabular}

Notes: Means with standard errors in parentheses. Observations are weighted by the appropriate Census sampling weight. Annual hours include zero values. Labor force attachment equals one if annual hours are greater than zero. Conditional annual hours include only positive values for annual hours. To facilitate comparisons between samples, bolded values in the rows for the sample with children represent a statistically significant difference in means at the 5 percent level relative to the sample without children. 
Table 3. Determinants of Annual Hours of Work by Sexual Orientation and Earner Status

Panel A: Oridinary Least Squares Coefficients and Standard Errors

\begin{tabular}{|c|c|c|c|c|}
\hline & $\begin{array}{l}\text { Married Women } \\
\text { (1) }\end{array}$ & $\begin{array}{l}\text { Lesbian } \\
\text { (2) }\end{array}$ & $\begin{array}{c}\text { Secondary Earner } \\
\text { Lesbian } \\
\text { (3) }\end{array}$ & $\begin{array}{c}\text { Primary Earner } \\
\text { Lesbian } \\
\text { (4) }\end{array}$ \\
\hline \multicolumn{5}{|l|}{ Children in the Housebold } \\
\hline Number of Children $<6$ & $\begin{array}{l}-388.732 \\
(1.650)^{* *}\end{array}$ & $\begin{array}{c}-144.144 \\
(29.633)^{* *}\end{array}$ & $\begin{array}{c}\mathbf{- 1 9 3 . 5 7 4} \\
(41.694)^{* *}\end{array}$ & $\begin{array}{c}\mathbf{- 8 8 . 3 5 0} \\
(34.130)^{* *}\end{array}$ \\
\hline Number of Children 6-17 & $\begin{array}{l}-154.528 \\
(1.088)^{* *}\end{array}$ & $\begin{array}{c}\mathbf{- 5 5 . 0 7 0} \\
(20.041)^{* *}\end{array}$ & $\begin{array}{c}\mathbf{- 7 9 . 2 4 9} \\
(29.846)^{* *}\end{array}$ & $\begin{array}{l}\mathbf{- 3 1 . 4 7 3} \\
(22.831)\end{array}$ \\
\hline Log Hourly Wage & $\begin{array}{c}435.983 \\
(2.555)^{* *}\end{array}$ & $\begin{array}{c}121.318 \\
(26.561)^{* *}\end{array}$ & $\begin{array}{c}-164.286 \\
(42.192)^{* *}\end{array}$ & $\begin{array}{l}\mathbf{- 3 8 . 9 5 7} \\
(39.344)\end{array}$ \\
\hline Partner's Log Hourly Wage & $\begin{array}{l}-325.424 \\
(2.474)^{* *}\end{array}$ & $\begin{array}{c}-66.716 \\
(23.556)^{* *}\end{array}$ & $\begin{array}{c}306.681 \\
(42.817)^{* *}\end{array}$ & $\begin{array}{c}\mathbf{5 5 . 8 0 1} \\
(30.121)\end{array}$ \\
\hline Family Non-Labor Income $/ \$ 1000$ & $\begin{array}{c}-4.053 \\
(0.068)^{* *}\end{array}$ & $\begin{array}{c}-4.475 \\
(0.777)^{* *}\end{array}$ & $\begin{array}{c}-6.172 \\
(1.238)^{* *}\end{array}$ & $\begin{array}{c}-2.708 \\
(0.885)^{* *}\end{array}$ \\
\hline $\begin{array}{l}\text { Observations } \\
\text { R-Squared }\end{array}$ & $\begin{array}{c}965469 \\
0.17\end{array}$ & $\begin{array}{l}6502 \\
0.06\end{array}$ & $\begin{array}{l}3251 \\
0.10\end{array}$ & $\begin{array}{l}3251 \\
0.04\end{array}$ \\
\hline \multicolumn{5}{|c|}{ Panel B: Instrumental Variables Coefficients and Standard Errors } \\
\hline \multicolumn{5}{|l|}{ Children in the Housebold } \\
\hline Number of Children $<6$ & $\begin{array}{l}-387.372 \\
(1.651)^{* *}\end{array}$ & $\begin{array}{c}\mathbf{- 1 4 4 . 1 0 7} \\
(29.620)^{* *}\end{array}$ & $\begin{array}{c}\mathbf{- 1 9 3 . 1 4 4} \\
(41.640)^{* *}\end{array}$ & $\begin{array}{c}\mathbf{- 8 8 . 4 4 5} \\
(34.117)^{* *}\end{array}$ \\
\hline Number of Children 6-17 & $\begin{array}{l}-151.865 \\
(1.089)^{* *}\end{array}$ & $\begin{array}{c}\mathbf{- 5 5 . 3 8 7} \\
(20.064)^{* *}\end{array}$ & $\begin{array}{c}\mathbf{- 7 9 . 0 9 2} \\
(29.859)^{* *}\end{array}$ & $\begin{array}{l}\mathbf{- 3 1 . 8 9 1} \\
(22.839)\end{array}$ \\
\hline Log Hourly Wage & $\begin{array}{c}495.381 \\
(2.527)^{* *}\end{array}$ & $\begin{array}{c}128.848 \\
(27.111)^{* *}\end{array}$ & $\begin{array}{c}-176.362 \\
(44.280)^{* *}\end{array}$ & $\begin{array}{l}\mathbf{- 5 3 . 4 8 9} \\
(39.264)\end{array}$ \\
\hline Partner's Log Hourly Wage & $\begin{array}{l}-360.907 \\
(2.515)^{* *}\end{array}$ & $\begin{array}{c}-78.105 \\
(24.059) * *\end{array}$ & $\begin{array}{c}314.655 \\
(45.336)^{* *}\end{array}$ & $\begin{array}{c}61.200 \\
(30.479)^{*}\end{array}$ \\
\hline Family Non-Labor Income $/ \$ 1000$ & $\begin{array}{c}-4.026 \\
(0.067)^{* *}\end{array}$ & $\begin{array}{c}-4.469 \\
(0.777)^{* *}\end{array}$ & $\begin{array}{c}-6.166 \\
(1.239)^{* *}\end{array}$ & $\begin{array}{c}-2.717 \\
(0.886)^{* *}\end{array}$ \\
\hline Observations & 965469 & 6502 & 3251 & 3251 \\
\hline R-Squared & 0.16 & 0.06 & 0.10 & 0.04 \\
\hline
\end{tabular}

Notes: Estimated coefficients with robust standard errors in parentheses. Observations are weighted by the appropriate Census sampling weight. Statistically significant coefficient estimates are indicated by a single asterisk $(p<0.05)$ or double asterisk $(p<0.01)$. See text for description of instruments in the instrumental variables regression. To facilitate comparisons between sexual orientation groups, bolded values in columns $2-4$ represent a statistically significant difference in estimated coefficients at the 5 percent level relative to column 1 . In addition to the variables listed, each regression also include three controls for education, five control variables for age, one for metropolitan area, eight for region, and a constant. 
Table 4. DiNardo, Fortin, and Lemieux Decomposition for Annual Hours by Earner Status

\begin{tabular}{lccc}
\hline & & & \\
\hline & $\begin{array}{c}\text { All Lesbian vs. } \\
\text { Married }\end{array}$ & $\begin{array}{c}\text { Secondary Lesbian } \\
\text { vs. Married }\end{array}$ & $\begin{array}{c}\text { Primary Lesbian vs. } \\
\text { Married }\end{array}$ \\
\hline Total Annual Hours Gap & $\mathbf{5 8 8 . 7 5 5}$ & $\mathbf{3 5 1 . 8 1 0}$ & $\mathbf{8 2 6 . 3 3 7}$ \\
Attributable to Differences in All Characteristics & 195.445 & 210.765 & 125.748 \\
$\quad$ Extensive Margin) & 97.441 & 132.111 & 36.277 \\
$\quad$ (Intensive Margin) & 98.004 & 78.655 & 89.471 \\
Children & 121.539 & 194.124 & 75.837 \\
$\quad$ Extensive Margin) & 52.313 & 90.705 & 20.039 \\
$\quad$ (Intensive Margin) & 69.226 & 103.419 & 55.799 \\
Log Hourly Wage & -4.223 & -14.629 & -17.281 \\
Partner Log Hourly Wage & 21.492 & -18.274 & 30.066 \\
Non-Labor Income & -4.341 & -7.366 & 0.080 \\
Education & 50.963 & 52.124 & 32.271 \\
Age & 0.633 & -5.392 & 3.480 \\
Metropolitan Area & 17.634 & 18.202 & -2.793 \\
Region & -8.251 & -8.024 & 4.088 \\
Unexplained from Differences in Characteristics & 393.310 & 141.045 & 700.589 \\
\hline
\end{tabular}

Notes: The total annual hours gap, which is calculated as the lesbian subsample average minus the married average, is decomposed into the portion attributable to differences in the distribution of observable characteristics and differences unexplained by the distribution of these characteristics. We further decompose the portion due to observable characteristics into subcategories to illustrate the relative importance of particular observable characteristics in the order of Children, Log Hourly Wage, Partner's Log Hourly Wage, Non-Labor Income, Education, Age, Metropolitan Area, and Region. See text for a description of the calculation of the role of the extensive and intensive margin. 
Table 5. Labor Force Attachment and the Distribution of Conditional Annual Hours by Sexual Orientation and Earner Status

\begin{tabular}{|c|c|c|c|c|}
\hline & $\begin{array}{c}\text { Married Women } \\
\text { (1) }\end{array}$ & $\begin{array}{l}\text { Lesbian } \\
\text { (2) }\end{array}$ & $\begin{array}{l}\text { Secondary Earner } \\
\text { Lesbian } \\
\text { (3) }\end{array}$ & $\begin{array}{c}\text { Primary Earner } \\
\text { Lesbian } \\
\text { (4) }\end{array}$ \\
\hline Labor Force Attachment & $\begin{array}{c}0.787 \\
(0.409)\end{array}$ & $\begin{array}{c}\mathbf{0 . 9 4 2} \\
(0.233)\end{array}$ & $\begin{array}{c}\mathbf{0 . 8 9 8} \\
(0.303)\end{array}$ & $\begin{array}{c}\mathbf{0 . 9 8 7} \\
(0.114)\end{array}$ \\
\hline Labor Force Attachment Gap & & 0.155 & 0.110 & 0.200 \\
\hline \multicolumn{5}{|l|}{ The Distribution of Conditional Annual Hours } \\
\hline Less than Full Attachment & $\begin{array}{l}0.388 \\
(0.487)\end{array}$ & $\begin{array}{l}\mathbf{0 . 1 9 5} \\
(0.396)\end{array}$ & $\begin{array}{c}\mathbf{0 . 2 8 7} \\
(0.452)\end{array}$ & $\begin{array}{c}\mathbf{0 . 1 1 1} \\
(0.315)\end{array}$ \\
\hline Less than Full Attachment Gap & & -0.193 & -0.102 & -0.277 \\
\hline Full Attachment & $\begin{array}{l}0.431 \\
(0.495)\end{array}$ & $\begin{array}{l}\mathbf{0 . 4 5 1} \\
(0.498)\end{array}$ & $\begin{array}{c}0.442 \\
(0.497)\end{array}$ & $\begin{array}{c}\mathbf{0 . 4 5 9} \\
(0.498)\end{array}$ \\
\hline Full Attachment Gap & & 0.020 & 0.011 & 0.028 \\
\hline Greater than Full Attachment & $\begin{array}{l}0.180 \\
(0.384)\end{array}$ & $\begin{array}{l}\mathbf{0 . 3 5 4} \\
(0.478)\end{array}$ & $\begin{array}{c}\mathbf{0 . 2 7 1} \\
(0.444)\end{array}$ & $\begin{array}{c}\mathbf{0 . 4 2 9} \\
(0.495)\end{array}$ \\
\hline Greater than Full Attachment Gap & & 0.174 & 0.091 & 0.249 \\
\hline Observations & 965469 & 6502 & 3251 & 3251 \\
\hline Obs. with Annual Hours $>0$ & 761541 & 6118 & 2908 & 3210 \\
\hline
\end{tabular}




\section{Table 6. DFL Results for Labor Force Attachment and the Distribution of Conditional Annual Hours By Earner Status}

Panel A: Differences in Labor Force Attachment (Annual Hours greater than 0)

\begin{tabular}{lccc}
\hline & $\begin{array}{c}\text { All Lesbian vs. } \\
\text { Married }\end{array}$ & $\begin{array}{c}\text { Secondary Lesbian } \\
\text { vs. Married }\end{array}$ & $\begin{array}{c}\text { Primary Lesbian vs. } \\
\text { Married }\end{array}$ \\
\hline Total Labor Force Attachment Gap & $\mathbf{0 . 1 5 5}$ & $\mathbf{0 . 1 1 0}$ & $\mathbf{0 . 2 0 0}$ \\
Attributable to Differences in All Characteristics & 0.047 & 0.069 & 0.016 \\
$\quad$ Children & 0.025 & 0.048 & 0.009 \\
$\quad$ Other Charateristics & 0.022 & 0.022 & 0.007 \\
Unexplained from Differences in Characteristics & 0.108 & 0.041 & 0.183 \\
\hline
\end{tabular}

Panel B: Differences in the Distribution of Conditional Annual Hours

Less than Full Attachment (Conditional Annual Hours between 1 and 1749)

Total Less than Full Attachment Gap $\quad \mathbf{- 0 . 1 9 3}$

$-0.102-0.277$

Attributable to Differences in All Characteristics

$-0.084$

$-0.064$

$-0.089$

Children

$-0.048$

$-0.078$

$-0.036$

Other Charateristics

$-0.035$

0.013

$-0.053$

Unexplained from Differences in Characteristics

$-0.110$

$-0.037$

$-0.188$

Full Attachment (Conditional Annual Hours between 1750 and 2080)

$\begin{array}{lccc}\text { Total Full Attachment Gap } & \mathbf{0 . 0 2 0} & \mathbf{0 . 0 1 1} & \mathbf{0 . 0 2 8} \\ \text { Attributable to Differences in All Characteristics } & 0.011 & 0.009 & 0.011 \\ \quad \text { Children } & -0.004 & 0.025 & -0.024 \\ \quad \text { Other Charateristics } & 0.015 & -0.016 & 0.034 \\ \text { Unexplained from Differences in Characteristics } & 0.009 & 0.002 & 0.017\end{array}$

Greater than Full Attachment (2081 Conditional Annual Hours or above)

\begin{tabular}{llll} 
Total Greater than Full Attachment Gap & $\mathbf{0 . 1 7 4}$ & $\mathbf{0 . 0 9 1}$ & $\mathbf{0 . 2 4 9}$ \\
Attributable to Differences in All Characteristics & 0.073 & 0.055 & 0.079 \\
$\quad$ Children & 0.053 & 0.052 & 0.060 \\
$\quad$ Other Charateristics & 0.020 & 0.003 & 0.019 \\
Unexplained from Differences in Characteristics & 0.101 & 0.036 & 0.170 \\
\hline
\end{tabular}

Notes: The total labor force attachment or conditional annual hours gap, which is calculated as the lesbian subsample average minus the married average, is decomposed into the portion attributable to differences in the distribution of observable characteristics and differences unexplained by these characteristics. We further decompose the portion due to observable characteristics into the portion due to children and the portion due to all other characteristics (Log Hourly Wage, Partner's Log Hourly Wage, Non-Labor Income, Education, Age, Metropolitan Area, and Region). 
Appendix Table 1. Selected Descriptive Statistics by Sexual Orientation and Earner Status

\begin{tabular}{|c|c|c|c|c|}
\hline & $\begin{array}{c}\text { Married Women } \\
\text { (1) }\end{array}$ & $\begin{array}{l}\text { Lesbian } \\
\text { (2) }\end{array}$ & $\begin{array}{c}\text { Secondary Earner } \\
\text { Lesbian } \\
\text { (3) }\end{array}$ & $\begin{array}{c}\text { Primary Earner } \\
\text { Lesbian } \\
\text { (4) }\end{array}$ \\
\hline Usual Weekly Hours if $>0$ & $\begin{array}{l}36.812 \\
(11.708)\end{array}$ & $\begin{array}{l}42.452 \\
(9.637)\end{array}$ & $\begin{array}{l}40.295 \\
(9.926)\end{array}$ & $\begin{array}{l}44.419 \\
(8.923)\end{array}$ \\
\hline Weeks Last Year if $>0$ & $\begin{array}{l}45.789 \\
(11.756)\end{array}$ & $\begin{array}{l}\mathbf{4 8 . 2 6 5} \\
(8.876)\end{array}$ & $\begin{array}{c}\mathbf{4 6 . 6 5 8} \\
(10.739)\end{array}$ & $\begin{array}{l}49.730 \\
(6.400)\end{array}$ \\
\hline Part Time $(0<$ hours $<35)$ & $\begin{array}{l}0.278 \\
(0.448)\end{array}$ & $\begin{array}{l}\mathbf{0 . 1 0 2} \\
(0.303)\end{array}$ & $\begin{array}{c}\mathbf{0 . 1 6 2} \\
(0.368)\end{array}$ & $\begin{array}{c}\mathbf{0 . 0 4 8} \\
(0.213)\end{array}$ \\
\hline Children in the Household & & & & \\
\hline Households with Children & $\begin{array}{l}0.661 \\
(0.473)\end{array}$ & $\begin{array}{l}\mathbf{0 . 2 0 5} \\
(0.404)\end{array}$ & $\begin{array}{c}\mathbf{0 . 2 0 4} \\
(0.403)\end{array}$ & $\begin{array}{c}\mathbf{0 . 2 0 5} \\
(0.404)\end{array}$ \\
\hline Number of Children if $>0$ & $\begin{array}{l}1.933 \\
(0.923)\end{array}$ & $\begin{array}{l}1.562 \\
(0.796)\end{array}$ & $\begin{array}{c}1.560 \\
(0.798)\end{array}$ & $\begin{array}{c}1.564 \\
(0.794)\end{array}$ \\
\hline Households with Children $<6$ & $\begin{array}{l}0.283 \\
(0.450)\end{array}$ & $\begin{array}{l}\mathbf{0 . 0 8 6} \\
(0.280)\end{array}$ & $\begin{array}{l}\mathbf{0 . 0 8 6} \\
(0.281)\end{array}$ & $\begin{array}{l}\mathbf{0 . 0 8 6} \\
(0.280)\end{array}$ \\
\hline Number of Children $<6$ if $>0$ & $\begin{array}{l}1.374 \\
(0.578)\end{array}$ & $\begin{array}{l}1.242 \\
(0.474)\end{array}$ & $\begin{array}{c}1.239 \\
(0.472)\end{array}$ & $\begin{array}{c}1.246 \\
(0.476)\end{array}$ \\
\hline Households with Children 6-17 & $\begin{array}{l}0.518 \\
(0.500)\end{array}$ & $\begin{array}{l}\mathbf{0 . 1 4 1} \\
(0.348)\end{array}$ & $\begin{array}{l}\mathbf{0 . 1 4 0} \\
(0.347)\end{array}$ & $\begin{array}{l}\mathbf{0 . 1 4 2} \\
(0.349)\end{array}$ \\
\hline Number of Children 6-17 if $>0$ & $\begin{array}{l}1.715 \\
(0.822)\end{array}$ & $\begin{array}{l}1.508 \\
(0.776)\end{array}$ & $\begin{array}{c}1.510 \\
(0.783)\end{array}$ & $\begin{array}{c}1.507 \\
(0.769)\end{array}$ \\
\hline Education & & & & \\
\hline Less than HS Grad & $\begin{array}{c}0.057 \\
(0.233)\end{array}$ & $\begin{array}{l}\mathbf{0 . 0 3 2} \\
(0.177)\end{array}$ & $\begin{array}{c}\mathbf{0 . 0 3 7} \\
(0.190)\end{array}$ & $\begin{array}{c}\mathbf{0 . 0 2 7} \\
(0.163)\end{array}$ \\
\hline HS Grad & $\begin{array}{l}0.268 \\
(0.443)\end{array}$ & $\begin{array}{l}\mathbf{0 . 1 2 0} \\
(0.325)\end{array}$ & $\begin{array}{c}\mathbf{0 . 1 3 6} \\
(0.343)\end{array}$ & $\begin{array}{c}\mathbf{0 . 1 0 4} \\
(0.305)\end{array}$ \\
\hline Some College & $\begin{array}{l}0.343 \\
(0.475)\end{array}$ & $\begin{array}{l}\mathbf{0 . 3 0 9} \\
(0.462)\end{array}$ & $\begin{array}{c}0.332 \\
(0.471)\end{array}$ & $\begin{array}{c}\mathbf{0 . 2 8 7} \\
(0.452)\end{array}$ \\
\hline College Grad & $\begin{array}{c}0.332 \\
(0.471)\end{array}$ & $\begin{array}{l}\mathbf{0 . 5 3 9} \\
(0.499)\end{array}$ & $\begin{array}{c}\mathbf{0 . 4 9 5} \\
(0.500)\end{array}$ & $\begin{array}{c}\mathbf{0 . 5 8 2} \\
(0.493)\end{array}$ \\
\hline Age & & & & \\
\hline Age 25-29 & $\begin{array}{c}0.118 \\
(0.323)\end{array}$ & $\begin{array}{l}\mathbf{0 . 1 0 2} \\
(0.303)\end{array}$ & $\begin{array}{c}0.115 \\
(0.319)\end{array}$ & $\begin{array}{l}\mathbf{0 . 0 9 0} \\
(0.286)\end{array}$ \\
\hline Age 30-34 & $\begin{array}{c}0.169 \\
(0.375)\end{array}$ & $\begin{array}{l}0.176 \\
(0.381)\end{array}$ & $\begin{array}{c}0.178 \\
(0.382)\end{array}$ & $\begin{array}{c}0.174 \\
(0.379)\end{array}$ \\
\hline Age 35-39 & $\begin{array}{c}0.212 \\
(0.409)\end{array}$ & $\begin{array}{l}\mathbf{0 . 2 7 9} \\
(0.448)\end{array}$ & $\begin{array}{l}\mathbf{0 . 2 8 0} \\
(0.449)\end{array}$ & $\begin{array}{l}\mathbf{0 . 2 7 7} \\
(0.447)\end{array}$ \\
\hline Age 40-44 & $\begin{array}{c}0.213 \\
(0.409)\end{array}$ & $\begin{array}{c}0.214 \\
(0.410)\end{array}$ & $\begin{array}{c}0.203 \\
(0.402)\end{array}$ & $\begin{array}{l}0.225 \\
(0.417)\end{array}$ \\
\hline Age 45-49 & $\begin{array}{c}0.182 \\
(0.386)\end{array}$ & $\begin{array}{l}\mathbf{0 . 1 4 6} \\
(0.353)\end{array}$ & $\begin{array}{l}\mathbf{0 . 1 3 9} \\
(0.346)\end{array}$ & $\begin{array}{l}\mathbf{0 . 1 5 3} \\
(0.360)\end{array}$ \\
\hline Age $50-54$ & $\begin{array}{l}0.106 \\
(0.308)\end{array}$ & $\begin{array}{l}\mathbf{0 . 0 8 3} \\
(0.276)\end{array}$ & $\begin{array}{l}\mathbf{0 . 0 8 5} \\
(0.279)\end{array}$ & $\begin{array}{l}\mathbf{0 . 0 8 2} \\
(0.274)\end{array}$ \\
\hline Metropolitan Area & $\begin{array}{c}0.715 \\
(0.452)\end{array}$ & $\begin{array}{l}\mathbf{0 . 8 6 1} \\
(0.346)\end{array}$ & $\begin{array}{c}\mathbf{0 . 8 6 0} \\
(0.347)\end{array}$ & $\begin{array}{c}\mathbf{0 . 8 6 1} \\
(0.346)\end{array}$ \\
\hline
\end{tabular}




\section{Appendix Table 1. Selected Descriptive Statistics by Sexual Orientation and Earner Status}

(cont.)

\begin{tabular}{lcccc}
\hline & Married Women & Lesbian & Secondary Earner \\
& $(1)$ & $(2)$ & $\begin{array}{c}\text { Primary Earner } \\
\text { Lesbian } \\
(3)\end{array}$ & $(4)$ \\
\hline Region & & & & \\
New England & 0.062 & $\mathbf{0 . 0 8 9}$ & $\mathbf{0 . 0 8 9}$ & $\mathbf{0 . 0 8 9}$ \\
& $(0.241)$ & $(0.285)$ & $(0.285)$ & $(0.285)$ \\
Middle Atlantic & 0.143 & $\mathbf{0 . 1 2 4}$ & $\mathbf{0 . 1 2 3}$ & $\mathbf{0 . 1 2 5}$ \\
& $(0.350)$ & $(0.330)$ & $(0.329)$ & $(0.331)$ \\
East North Central & 0.195 & $\mathbf{0 . 1 3 6}$ & $\mathbf{0 . 1 3 5}$ & $\mathbf{0 . 1 3 6}$ \\
& $(0.396)$ & $(0.342)$ & $(0.342)$ & $(0.343)$ \\
West North Central & 0.091 & $\mathbf{0 . 0 6 8}$ & $\mathbf{0 . 0 6 8}$ & $\mathbf{0 . 0 6 8}$ \\
& $(0.288)$ & $(0.252)$ & $(0.252)$ & $(0.252)$ \\
South Atlantic & 0.175 & $\mathbf{0 . 1 9 4}$ & $\mathbf{0 . 1 9 5}$ & $\mathbf{0 . 1 9 4}$ \\
& $(0.380)$ & $(0.396)$ & $(0.396)$ & $(0.395)$ \\
East South Central & 0.070 & $\mathbf{0 . 0 3 0}$ & $\mathbf{0 . 0 3 0}$ & $\mathbf{0 . 0 3 1}$ \\
West South Central & $(0.256)$ & $(0.172)$ & $(0.170)$ & $(0.173)$ \\
& 0.093 & $\mathbf{0 . 0 6 7}$ & $\mathbf{0 . 0 6 8}$ & $\mathbf{0 . 0 6 6}$ \\
Mountain & $(0.290)$ & $(0.251)$ & $(0.252)$ & $(0.249)$ \\
Pacific & 0.063 & $\mathbf{0 . 0 7 0}$ & 0.070 & 0.069 \\
& $(0.243)$ & $(0.255)$ & $(0.256)$ & $(0.254)$ \\
Observations & 0.108 & $\mathbf{0 . 2 2 1}$ & $\mathbf{0 . 2 2 1}$ & $\mathbf{0 . 2 2 1}$ \\
\hline
\end{tabular}

Notes: Means with standard errors in parentheses. Observations are weighted by the appropriate Census sampling weight. To facilitate comparisons between sexual orientation groups, bolded values in columns 2-4 represent a statistically significant difference in means at the 5 percent level relative to column 1 . 
Appendix Table 2. Descriptive Statistics, OLS and IV Results by Earner Status (Householder Definition)

\begin{tabular}{|c|c|c|c|c|c|c|}
\hline & \multicolumn{2}{|c|}{ Means and Standard Deviations } & \multicolumn{2}{|c|}{ OLS Coefficients and Standard Errors } & \multicolumn{2}{|c|}{ IV Coefficients and Standard Errors } \\
\hline & $\begin{array}{l}\text { Secondary Earner } \\
\text { Lesbian } \\
(1) \\
\end{array}$ & $\begin{array}{l}\text { Primary Earner } \\
\text { Lesbian } \\
(2) \\
\end{array}$ & $\begin{array}{l}\text { Secondary Earner } \\
\text { Lesbian } \\
\text { (3) }\end{array}$ & $\begin{array}{l}\text { Primary Earner } \\
\text { Lesbian } \\
(4)\end{array}$ & $\begin{array}{l}\text { Secondary Earner } \\
\text { Lesbian } \\
(5)\end{array}$ & $\begin{array}{l}\text { Primary Earner } \\
\text { Lesbian } \\
(6) \\
\end{array}$ \\
\hline Annual Hours & $\begin{array}{l}\mathbf{1 8 7 1 . 7 6 8} \\
(812.603)\end{array}$ & $\begin{array}{c}2026.965 \\
(720.393)\end{array}$ & & & & \\
\hline Labor Force Attachment & $\begin{array}{c}\mathbf{0 . 9 2 5} \\
(0.264)\end{array}$ & $\begin{array}{c}\mathbf{0 . 9 6 0} \\
(0.196)\end{array}$ & & & & \\
\hline Conditional Annual Hours & $\begin{array}{c}2024.262 \\
(636.669)\end{array}$ & $\begin{array}{l}2111.534 \\
(601.663)\end{array}$ & & & & \\
\hline \multicolumn{7}{|c|}{ The Distribution of Conditional Annual Hours } \\
\hline Less than Full Attachment & $\begin{array}{c}\mathbf{0 . 2 8 7} \\
(0.452)\end{array}$ & $\begin{array}{c}\mathbf{0 . 1 1 1} \\
(0.315)\end{array}$ & & & & \\
\hline Full Attachment & $\begin{array}{c}0.442 \\
(0.497)\end{array}$ & $\begin{array}{c}\mathbf{0 . 4 5 9} \\
(0.498)\end{array}$ & & & & \\
\hline Greater than Full Attachment & $\begin{array}{c}\mathbf{0 . 2 7 1} \\
(0.444)\end{array}$ & $\begin{array}{c}\mathbf{0 . 4 2 9} \\
(0.495)\end{array}$ & & & & \\
\hline Children in the Household & & & & & & \\
\hline Number of Children $<6$ & $\begin{array}{l}\mathbf{0 . 1 0 7} \\
(0.375)\end{array}$ & $\begin{array}{l}\mathbf{0 . 1 0 7} \\
(0.375)\end{array}$ & $\begin{array}{c}-147.722 \\
(43.033)^{* *}\end{array}$ & $\begin{array}{c}\mathbf{- 1 4 0 . 8 4 6} \\
(41.280)^{* *}\end{array}$ & $\begin{array}{c}\mathbf{- 1 4 7 . 1 0 5} \\
(43.013)^{* *}\end{array}$ & $\begin{array}{c}\mathbf{- 1 4 1 . 4 3 2} \\
(41.301)^{* *}\end{array}$ \\
\hline Number of Children 6-17 & $\begin{array}{l}\mathbf{0 . 2 1 3} \\
(0.599)\end{array}$ & $\begin{array}{l}\mathbf{0 . 2 1 3} \\
(0.602)\end{array}$ & $\begin{array}{c}\mathbf{- 8 3 . 6 6 1} \\
(29.817)^{* *}\end{array}$ & $\begin{array}{l}-27.557 \\
(26.013)\end{array}$ & $\begin{array}{c}\mathbf{- 8 4 . 7 3 6} \\
(29.811)^{* *}\end{array}$ & $\begin{array}{l}-27.276 \\
(26.032)\end{array}$ \\
\hline Log Hourly Wage & $\begin{array}{c}2.720 \\
(0.503)\end{array}$ & $\begin{array}{c}2.836 \\
(0.506)\end{array}$ & $\begin{array}{c}138.016 \\
(39.330)^{* *}\end{array}$ & $\begin{array}{c}\mathbf{5 8 . 1 3 9} \\
(35.480)\end{array}$ & $\begin{array}{c}131.614 \\
(40.499)^{* *}\end{array}$ & $\begin{array}{c}76.522 \\
(35.940)^{*}\end{array}$ \\
\hline Partner's Log Hourly Wage & $\begin{array}{l}2.837 \\
(0.506)\end{array}$ & $\begin{array}{l}2.719 \\
(0.503)\end{array}$ & $\begin{array}{l}\mathbf{- 6 5 . 4 8 0} \\
(34.330)\end{array}$ & $\begin{array}{l}\mathbf{- 1 4 . 0 3 7} \\
(32.261)\end{array}$ & $\begin{array}{c}\mathbf{- 8 1 . 0 1 5} \\
(36.309)^{*}\end{array}$ & $\begin{array}{l}\mathbf{- 1 8 . 9 1 0} \\
(31.922)\end{array}$ \\
\hline Family Non-Labor Income $/ \$ 1000$ & $\begin{array}{c}4.906 \\
(17.370)\end{array}$ & $\begin{array}{c}4.795 \\
(16.931)\end{array}$ & $\begin{array}{c}-3.404 \\
(1.084)^{* *}\end{array}$ & $\begin{array}{c}-5.672 \\
(1.055)^{* *}\end{array}$ & $\begin{array}{c}-3.406 \\
(1.084)^{* *}\end{array}$ & $\begin{array}{c}-5.654 \\
(1.054)^{* *}\end{array}$ \\
\hline $\begin{array}{l}\text { Observations } \\
\text { Obs. with Annual Hours }>0 \\
\text { R-Squared }\end{array}$ & $\begin{array}{l}3251 \\
3007\end{array}$ & $\begin{array}{l}3251 \\
3111\end{array}$ & 0.06 & 0.07 & $\begin{array}{l}3251 \\
0.06\end{array}$ & 0.07 \\
\hline
\end{tabular}




\section{Appendix Table 3. DFL Results for Annual Hours, Labor Force Attachment and the Distribution of Conditional Annual Hours By Earner Status (Householder Definition)}

Panel A: Differences in Annual Hours

\begin{tabular}{lcc}
\hline & $\begin{array}{c}\text { Secondary Lesbian } \\
\text { vs. Married }\end{array}$ & $\begin{array}{c}\text { Primary Lesbian vs. } \\
\text { Married }\end{array}$ \\
\hline Total Annual Hours Gap & $\mathbf{5 1 1 . 7 5 8}$ & $\mathbf{6 6 6 . 9 5 5}$ \\
Attributable to Differences in All Characteristics & 190.701 & 183.696 \\
$\quad$ Children & 144.184 & 105.919 \\
$\quad$ Other Charateristics & 46.518 & 77.777 \\
Unexplained from Differences in Characteristics & 321.057 & 483.259
\end{tabular}

Panel B: Differences in Labor Force Attachment (Annual Hours greater than 0)

Total Labor Force Attachment Gap

Attributable to Differences in All Characteristics Children

Other Charateristics

Unexplained from Differences in Characteristics

\subsection{7}

0.173

0.055

0.038

0.018

0.082
0.025

0.014

0.011

0.147

Panel C: Differences in the Distribution of Conditional Annual Hours

Less than Full Attachment (Conditional Annual Hours between 1 and 1749)

$\begin{array}{lcr}\text { Total Less than Full Attachment Gap } & \mathbf{- 0 . 1 6 6} & \mathbf{- 0 . 2 2 1} \\ \text { Attributable to Differences in All Characteristics } & -0.060 & -0.115 \\ \quad \text { Children } & -0.048 & -0.052 \\ \quad \text { Other Charateristics } & -0.012 & -0.063 \\ \text { Unexplained from Differences in Characteristics } & -0.105 & -0.106\end{array}$

Full Attachment (Conditional Annual Hours between 1750 and 2080)

$\begin{array}{lcr}\text { Total Full Attachment Gap } & \mathbf{0 . 0 1 3} & \mathbf{0 . 0 2 6} \\ \text { Attributable to Differences in All Characteristics } & -0.022 & 0.052 \\ \quad \text { Children } & -0.018 & 0.009 \\ \quad \text { Other Charateristics } & -0.004 & 0.042 \\ \text { Unexplained from Differences in Characteristics } & 0.035 & -0.025\end{array}$

Greater than Full Attachment (2081 Conditional Annual Hours or above)

\begin{tabular}{lcc} 
Total Greater than Full Attachment Gap & $\mathbf{0 . 1 5 2}$ & $\mathbf{0 . 1 9 4}$ \\
Attributable to Differences in All Characteristics & 0.082 & 0.063 \\
Children & 0.066 & 0.043 \\
Other Charateristics & 0.016 & 0.021 \\
Unexplained from Differences in Characteristics & 0.070 & 0.131 \\
\hline
\end{tabular}

Notes: The total annual hours, labor force attachment or conditional annual hours gap, which is calculated as the lesbian subsample average minus the married average, is decomposed into the portion attributable to differences in the distribution of observable characteristics and differences unexplained by these characteristics. We further decompose the portion due to observable characteristics into the portion due to children and the portion due to all other characteristics (Log Hourly Wage, Partner's Log Hourly Wage, Non-Labor Income, Education, Age, Metropolitan Area, and Region). 